\title{
Taking Conservatives Seriously: A Moral Justification for Affirmative Action and Reparations
}

\author{
Kim Forde-Mazrui $\dagger$
}

\section{TABLE OF Contents}

Introduction.

I. Corrective Racial Justice: The Prima Facie Case for Societal

Responsibility

A. Society Wrongfully Caused Harm.

1. The Nature of the Harm

2. The Causal Relationship to Historic Discrimination

B. Society's Obligation to Remedy the Harm

II. Objections to the Prima Facie Case: Problems of

Intergenerational Responsibility

A. Identifying Current Society with Past Discrimination.

1. The Wrongfulness of Slavery and Segregation

2. The Collective Responsibility of Past Society

3. The Collective Responsibility of Current Society

B. Proximate Causation: "Breaking" the Chain of Societal

Responsibility?

1. The Significance of Intervening Choice

Copyright (C 2004 California Law Review, Inc. Califomia Law Review, Inc. (CLR) is a Califomia nonprofit corporation. CLR and the authors are solely responsible for the content of their publications.

$\dagger \quad$ Professor of Law and Barron F. Black Research Professor, University of Virginia; Director, University of Virginia Center for the Study of Racc and Law; Visiting Professor of Law, University of Michigan (2003-04) 1 am grateful to many people for helpful comments and discussions about this project. I am especially grateful for the extensive comments I received on earlier drafts from Laurie Balfour, Rick Banks, Len Baynes, Anne Coughlin, Tino Cuellar, Dave Glazier, Joe Kennedy, Mike Klarman, Daryl Levinson, Clarisa Long, Dan Ortiz, Reggie Robinson, Jim Ryan, Rebecca Scott, Bob Scott, Bill Stuntz, and Bruce Thomas. 1 also received helpful feedback from the participants in workshops at Arizona State University, Georgetown Law Center, Stanford University, Syracuse University, the University of Michigan, the University of Pennsylvania, and the University of Virginia, as well as participants in the Mid-Atlantic and Northeast People of Color Legal Scholarship Conferences in 2001. The University of Virginia Law Library staff provided superb reference assistance. A special thanks to Tihisa Braziel, Sebastian Edwards, Madeleine Findley, Nicola Laing, Marcia Murchison, Terrica Redfield, and Davené Swinson for their diligent research assistance. 
2. The Significance of Time 737

III. Mediating the Moral Conflict: How Can Society Fulfill Its

Responsibility?

A. The Difficulties of Identifying the Effects of Past

Discrimination .

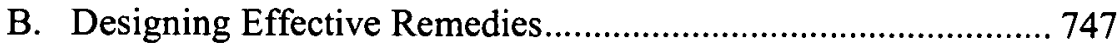

Conclusion 


\title{
Taking Conservatives Seriously: A Moral Justification for Affirmative Action and Reparations
}

\author{
Kim Forde-Mazrui
}

Underlying the debate over affirmative action and reparations for black Americans is a dispute about the extent to which American society is responsible for present effects of past racial discrimination. Although much has been written on the subject, the scholarship too often sheds more heat than light, and tends to be dominated by extreme positions incapable of taking opposing claims seriously. This Article weighs in on this debate in a novel and constructive manner. The Article defends a societal obligation to remedy past discrimination by accepting, rather than dismissing, principles of conservatives who oppose affirmative action and reparations. Taking conservatives seriously reveals two moral principles that support a societal obligation to remedy past discrimination. The first principle is that racial discrimination is unjust. The second principle is corrective justice: that one who wrongfully harms another is obligated to make amends. Applied to affirmative action, these principles support conservative claims that a state is obligated to make amends to white victims of racial preferences. These principles, however, also support America's responsibility for past societal discrimination against blacks. To the extent society participated in wrongful discrimination, society is obligated, as a matter of corrective justice, to make amends to its black victims. A potential moral conflict thus exists between society's obligation to refrain from "reverse" discrimination and its obligation to remedy past discrimination. That is, the moral case against affirmative action also supports a moral case in its favor.

The Article responds to the most serious objections to a societal obligation to remedy past discrimination. These include that America as a whole is not responsible for discrimination practiced by only some states and private actors, that it is unfair to hold current society responsible for discrimination by past society, and that blacks today ought not be viewed as victims of past discrimination, given the passage of time and the extent to which black people's choices have perpetuated their own disadvantage. This Article concludes that these objections fail to defeat America's 
responsibility for the consequences of her discriminatory history. America as a nation was responsible for protecting slavery and discrimination, a responsibility that belongs to the nation as a nation and therefore continues over time despite changeover in the American citizenry. American society is also responsible for black people's choices that may perpetuate their disadvantage because those choices reflect a foreseeable reaction to conditions created by societal discrimination. The moral imperative to remedy past discrimination, moreover, outweighs the risk of imprecision in doing so. Ultimately, conservative opposition to remedial policies is based on principles that counsel in favor of such policies as much as and arguably more than they counsel against them.

\section{INTRODUCTION}

In Grutter v. Bollinger, ${ }^{1}$ the U.S. Supreme Court declined to forbid affirmative action, leaving the question of its legitimacy to the American people to resolve. Despite the deep divisions within that debate, broad consensus exists on at least two critical points: slavery and discrimination ${ }^{2}$ against black Americans were wrong, and they should never happen again. Intense disagreement prevails, however, about the extent to which the effects (or "legacy") of past discrimination persist and the collective responsibility of society, if any, towards their amelioration. ${ }^{3}$ To one extreme are those who argue that the effects of past discrimination are pervasive and manifest in social and economic deprivation, institutionalized racism, and present discrimination. ${ }^{4}$ Such effects, some contend, exert such an

1. 123 S. Ct. 2325 (2003).

2. For purposes of this Article, the term "discrimination" refers to the practice of intentionally treating people differently bccause of their race.

3. The competing positions described in this paragraph do not exhaust all arguments that have been advanced, which are as numerous as the literature on race is voluminous. Nor do they necessarily correspond precisely to the positions of particular commentators. They are intended to illustrate broad categories of arguments typically reflected in debates about societal responsibility for past discrimination. The footnotes provide some references to specific commentators whose positions fall roughly within the broader approaches described in the text.

4. See, e.g., Charles R. Lawrence 111, The ld, the Ego, and Equal Protection: Reekoning with Unconscious Racism, 39 STAN. L. REv. 317 (1987) (arguing that unconscious racism, as the enduring mark of slavery, permeates American society); Jamie B. Raskin, Affirmative Action and Racial Reaction, 38 How. L.J. 521, 555 (1995) (defending affirmative action on the ground that the condition of black Americans is substantially impacted by the effects of employment and housing discrimination, segregation, disenfranchisement, violence, and slavery); Vincene Verdun, If the Shoe Fits, Wear It: An Analysis of Reparations to African Americans, 67 TUL. L. REv. 597, 664 (1993) (arguing that the economic effects of 300 years of oppression and discrimination mean that "the past of the Negro exists in the present" (quoting Whitney M. Young, Jr., Should There Be "Compensation" for Negroes?: "Domestic Marshall Plan," N.Y. Times MAG., Oct. 6, 1963, at 43)); Tuneen E. Chisolm, Comment, Sweep Around Your Own Front Door: Examining the Argument for Legislative African Ameriean Reparations, 147 U. PA. L. REv. 677, 687 (1999) (arguing that wealth inequality between whites and blacks has been structured over many generations through the systematic barriers of slavery, "Jim Crow" laws, de jure discrimination, and institutionalized racism (citing MELviN L. OLIVER \& 
oppressive and debilitating force on black people that society cannot fairly blame those blacks who engage in unproductive, irresponsible, or criminal conduct. ${ }^{5}$ They would place culpability instead with the U.S. government for human rights violations and argue that all thirty-six million black Americans residing in the United States today are entitled to full reparations. ${ }^{6}$ To the other extreme are opponents of racial remediation who claim that discrimination can no longer be blamed for the plight of blacks. ${ }^{7}$ They attribute exclusive responsibility for the social and economic disadvantages $^{8}$ disproportionately experienced by blacks to blacks themselves for eschewing opportunity in favor of crime and government dependence. ${ }^{9}$

Thomas M. Shapiro, Black Wealth/White Wealth: A New Perspective on Racial INEQUALITY 12-13 (1995))),

5. See, e.g., Paul Butler, Racially Based Jury Nullification: Black Power in the Criminal Justice System, 105 YALE L.J. 677, 680, 715-16 (1995) (arguing that black criminals should not be punished for retributive purposes because their crimes are a predictable reaction to pervasive racial subordination and white supremacy); see also PAUl. HARRIS, BLACK Rage Confronts THE LAW (1997) (arguing for a diminished capacity defense against criminal liability for crimes committed by black defendants in the heat of "black rage" caused by living in discriminatory environments)

6. An increasing number of books and articles discuss the question of reparations to black Americans for slavery and discrimination. See, e.g., Richard F. America, Paying the Social Debt: What White america OWes Black America (1993); Boris I. Bittker, The Case for Black Reparations (1973); Randall Robinson, The Debt: What america Owes to Blacks (2000); Graham Hughes, Reparations for Blacks?, 43 N.Y.U. L. REV. 1063 (1968); Mari J. Matsuda, Looking to the Bottom: Critical Legal Studies and Reparations, 22 HARV. C.R.-C.L. L. REV. 323 (1987); Charles J. Ogletree, Jr., Repairing the Past: New Efforts in the Reparations Debate in America, 38 HARv. C.R.-C.L. L. REv. 279 (2003); Verdun, supra note 4; Chisolm, supra note 4; Rhonda V. Magee, Note, The Master's Tools, from the Bottom Up: Responses to African-American Reparations Theory in Mainstream and Outsider Remedies Discourse, 79 VA. L. REv. 863 (1993).

Recently, Charles Ogletree and several leading civil rights and class action lawyers have begun organizing an effort to bring suit against the United States on behalf of black Americans seeking reparations for slavery. See Jack Hitt, Making thc Case for Racial Reparations: Does America Owe a Debt to the Descendants of Its Slaves, HARPER's MAG., Nov. 2000, at 37, 51. Ogletree recently published an essay surveying the reparations movement and detailing many of its most salient issues. See Ogletree, supra.

7. See, e.g., Richard J. Herrnstein \& Charles Murray, The Bell Curve: Intelligence and Class Structure in American Life 269-340 (1994) (claiming that there are innate differences in the cognitive abilities of racial groups); Ward Connerly, Affirmative Action Programs, Race Relations and the CCRI, 1 NEXUS 10, 19 (1996) (arguing that blacks no longer face serious discrimination and should therefore be required to compete economically on the same terms as everyone else); Girardeau A. Spann, Affirmative Action and Discrimination, 39 How. L.J. 1, 52-53 (1995) (arguing that any effects of societal discrimination that may still linger are too subtle and attenuated to justify remedial action); John B. Judis, Honor Code, New RePublic, Oct. 20, 1997, at 4 (arguing that underachievement of black schoolchildren is not due to past discrimination but to misguided policies that place a higher priority on racial integration than on quality education).

8. For purposes of this Article, "disadvantage" refers to the relatively inferior quality of life experieneed on average by blacks as compared to whites, as measured by conventional indicators of social and economic well-being, such as income and other wealth, academic achievement, health, and crime victimization. The term is not meant to beg the question whether such disadvantage is the responsibility of society or of black people to rectify.

9. See David Horowitz, Alternative to Affirmative Action? Study., Salon.com (June 23, 1997), at http://www.salon.eom/june97/columnists/horowitz2970623.html (attributing the inferior status of black Americans to poor decision making, cultural teachings, and bad behavior, including devaluing 
Some also cite cultural explanations for black disadvantage, claiming that the culture of black communities fosters oppositional attitudes and deviant behavior. ${ }^{10}$ Other commentators find themselves at various points in between. Some believe that society does have some responsibility for the condition of blacks, but that such responsibility continues to dissipate over time and generations, especially as claims from other disadvantaged groups compete for government relief. ${ }^{11}$ Others, also acknowledging the significance of past discrimination, nonetheless believe that blaming society for the condition of blacks should be resisted because it treats blacks paternalistically, and because race-based remedies generate resentment, perpetuate racial discord, and unfairly discriminate against innocent whites. And some people are simply tired - tired of being reminded of a history that largely predated their birth or arrival to this country, tired of feeling accused of shameful acts they never personally committed or condoned, tired of dwelling on the past. ${ }^{12}$ Entrenching themselves deeper into their positions,

education and parental responsibility); Christopher Jencks, Deadly Neighborhoods, NEw REPUBLIC, June 13, 1988, at 23 (reviewing William Julius Wilson, The Truly Disadvantaged: The Inner City, the Underclass, and Public Policy (1987)) (suggesting that much of idleness in the black community reflects voluntary choices by black men to take minimum wage jobs without benefits or potential for promotion).

10. See, e.g., George Gilder, Wealth AND Poverty 12-13 (Bantam Books 1982) (1981) (arguing that the War against Poverty led to workforce withdrawal and a breakdown in the black family structure); Richard D. Kahlenberg, The Remedy: Class, Race and Affirmative Action 20, 218 n.21 (1996) (suggesting that black culture substantially causes the lack of educational and financial achievement among blacks); Thomas Sowell, Civil Rights: Rhetoric oR Reality? 46-47 (1984) (attributing the decline in employment and the breakdown in the black family structure to poverty); Eleanor Brown, Black Like Me? "Gangsta" Culture, Clarence Thomas, and Afrocentric Academies, 75 N.Y.U. L. REV. 308 (2000) (arguing that "gangsta" norms have overrun inner city communities, leading black youth to reject mainstream opportunity-enhancing behaviors, such as educational achievement and law abidance); Dinesh D'Souza, Improving Culture to End Racism, 19 HARV. J.L. \& PUB. PoL'y 785 (1996) (arguing that the racial hierarchy in Amcrica is not due solely to racism, economic factors, or genes, but is due in significant part to cultural breakdown, particularly in the black community); Kimberly M. Copp, Note, Black Rage: The Illegitimacy of a Criminal Defense, $29 \mathrm{~J}$. MARSHALl L. REv. 205 (1995) (arguing that the primary impediment to black success is black culture, which contributes to family breakdown, poverty, and crime); Nicholas O. Berry, Is "Black Culture" Holding Blacks Back?, PHIL. INQuIRER, Aug. 18, 1993, at A11 (attributing low Scholastic Aptitude Test (SAT) scores by blacks to black culture's cmphasis on "oral tradition"); Seth Mydans, Black Identity vs. Success and Seeming "White," N.Y. TimES, Apr. 25, 1990, at B9 (arguing that a culture has emerged in the black eommunity that dcfines aeademic success as "acting white").

11. See, e.g., Eric A. Posner \& Adrian Vermeule, Reparations for Slavery and Other Historical Injustices, 103 COLUM. L. REv. 689, 746-47 (2003) (noting concern that reparations programs for one group will lead other groups to demand similar programs).

12. See, e.g., Connerly, supra note 7 , at 12 (quoting participants in a poll who stated they should not be held responsible for compensating black Americans for something their generation did not do); The Conversation, WASH. POST, July 23, 2000, at F1 ("As a white woman, I am tired of being blamed for slavery because-and only because- 1 am white, when the fact of the matter is I am descended from lrish and German immigrants who didn't arrive on Ellis Island until well after the Civil War." (quoting Peggy Sakagawa)); Joseph A. Patenaude, Letter to the Editor, Initiative 200: Tired of Being Scapegoat, Seattle Times, Oct. 25, 1998, at B11 ("[A]s a white male . . 1 am tired of being 'put down' and disparaged because 1 am who $1 \mathrm{am}$. 1 am blamed for all wrongs done to all minorities throughout history."). 
each side invokes increasingly vehement condemnations of the other. And while some commentators scramble to proclaim that "the problem of the twenty-first century will be the problem of the color line," 13 others will likely react-not again.

This Article addresses whether American society today bears any moral responsibility for the relatively inferior position of black Americans, to the extent such conditions result from the discrimination perpetrated against black Americans during the period of slavery, through segregation, and until (at the earliest) the adoption of national antidiscrimination laws in the $1960 \mathrm{~s} .{ }^{14}$ Although much has been written on the subject, particularly in the context of affirmative action and reparations, the literature tends to be dominated by extreme positions incapable of taking competing claims seriously.

Moreover, arguments advanced on both sides of this controversy often conflate concepts that should be kept distinct. For example, the proposition that past discrimination is causally related to present conditions is often assumed, erroneously, to imply that society as a whole is necessarily responsible for such conditions, or that black Americans bear no personal responsibility for their plight. ${ }^{15}$ Many arguments also assume responsibility

13. John hope Franklin, The Color line: Legacy for the Twenty-First Century 5 (1993); see also Paul Finkelman, Affirmative Action for the Master Class: The Creation of the Proslavery Constitution, 32 AKRON L. REv. 423, 470 (1999) (concluding that the problem of slavery and its legacy of raee discrimination is "the problem of the twenty-first century"). Such predictions are reiterations of W.E.B. Du Bois's prediction that "[ $t]$ he problem of the twentieth century is the problem of the colour line." See David Levering Lewis, W.E.B. Du Bois: Biography OF A RaCE, I 868-19 I9, at 251 (1993) (quoting W.E.B. Du BoIs, To the Nations of the World, in WRITINGS BY W.E.B. DuBoIs in Non-Periodical Literature Edited by Others 11, 11 (Herbert Aptheker ed., 1982)) (emphasis added).

14. This Article's focus is limited to American society's responsibility toward black Americans. This is not meant to imply that society bears no responsibility toward other minority groups that have experienced a history of discrimination in America. The relationship between any particular group and societal discrimination must be considered on a case-by-ease basis. Although some scholars have argued that the history of discrimination against black Americans makes them uniquely entitled to affirmative action, that question is outside the scope of this Article. See, e.g., Paul Brest \& Miranda Oshige, Affirmative Action for Whom?, 47 STAN. L. REv. 855, 900 (1995) ("'N]o other group compares to African Americans in the confluenee of the characteristics that argue for inelusion in affirmative action programs."); Roy L. Brooks, Race as an Under-Inclusive and Over-Inclusive Concept, 1 AfRAM. L. \& POL'Y REP. 9, 15 (1994) (“African Amerieans . . . are the only social group ... that did not come to this country of their own free will."); Alex M. Johnson, Jr., Defending the Use of Quotas in Affirmative Action: Attacking Racism in the Nineties, 1992 U. ILL. L. REv. 1043, 1071-73 (arguing tbat the unique expcrience of blacks justifies the use of racial quotas for their benefit); James Boyd White, What's Wrong With Our Talk About Race? On History, Particularity, and Affirmative Action, 100 Mich. L. Rev. 1927, 1932 (2002) ("[T]he situation of African Americans in our country is unique and makes unique claims upon us. 1 think black people have suffered a qualitatively different kind of discrimination from any other minority or race, and continue to do so.").

15. As explored below in Part 11.B, a causal relationship between past soeietal discrimination and present conditions affecting black Americans does not neeessarily imply that society is responsible for such conditions if the passage of time or contribution of blaek people's conduet justifies relieving society of whatever responsibility it initially may have had. 
to be exclusive, such that either society or blacks are responsible for racial inequities, but not both. ${ }^{16} \mathrm{~A}$ third point of confusion derives from the failure of many existing arguments to distinguish between the collective responsibility of America as a nation and the personal responsibility of its members for the perpetration of past discrimination. ${ }^{17}$ Finally, the question of whether society is responsible for certain conditions is often conflated with the question of how society should fulfill such responsibility. ${ }^{18}$

This Article attempts to bridge the divide between advocates and opponents of affirmative action in two ways. First, the Article bridges the logical divide by expressly separating the concepts conflated by much of the existing literature. Second, the Article bridges the rhetorical divide by employing modes of reasoning frequently used by conservative ${ }^{19}$ opponents of affirmative action and reparations to argue that American society bears at least some moral responsibility for the effects of past societal discrimination. Indeed, the thesis of this Article is that principles central to arguments made against affirmative action support as much as negate a societal obligation to remedy effects of past racial injustice. Consider: Opponents of affirmative action often frame their position in moral terms. ${ }^{20}$ They argue that racial discrimination is immoral, that

16. For further discussion of this point, see infra notes 169-74 and accompanying text.

17. For further discussion of this point, see infra notes 157-59 and accompanying text.

18. Opponents of racial preferences or monetary reparations for blacks, who may have legitimate objections to such policies, often erroncously conclude that their position logically requires them to reject wbolesale any societal responsibility for the inferior conditions in which black Americans live. Many advocates of racial preferences or reparations appear to make the converse and equally mistaken inference from the existence of societal responsibility to the conclusion that any policy intended to fulfill such responsibility is necessarily justified. If the discourse on racial remediation is to be constructive, the distinction between societal responsibility and the means for fulfilling it, between why and how, must be kept clear. Parts I and Il of this Article primarily discuss the first question of societal responsibility, and Part 111 then considers some implications of such responsibility for the means by which it may be fulfilled.

19. For convenience of exposition, this Article will sometimes use the term "conservative" to denote those who oppose government-sponsored efforts to benefit black Americans, such as affirmative action and proposals for monetary reparations. Clearly not all who adhere to politically conservative principles oppose such remedial policies and not all who oppose them are conservative. The overlap is substantial enough, however, to justify the shorthand, recognizing its imperfection as a proxy.

20. See, e.g., Roy L. Brooks, The Affirmative Action Issue: Law, Policy, and Morality, 22 ConN. L. REv. 323, 353 (1990) (reviewing philosophical arguments for concluding that affirmative action is immoral and unjust); Nicholas Capaldi, The Liberal Paradigm in Affirmative Action Law, 43 LoyolA L. REV. 525, 534 (1998) (arguing that "affirmative action is immoral" because it violates "at least six fundamental moral presuppositions of American society"); Orrin Hatch, The Son of Separate But Equal: The Supreme Court and Affirmative Action, in A Blueprint For Judicial Reform 63, 75 (Patrick B. McGuigan \& Randall R. Rader eds., 1981) (criticizing affirmative action programs as "immoral" and "unconstitutional"); Alex M. Johnson, Jr., The Underrepresentation of Minorities in the Legal Profession: A Critical Race Theorist's Perspective, $95 \mathrm{MICH}$. L. REV. 1005, 1053 (1997) (describing as one of the prevailing arguments against affirmative action that all racial discrimination is unjust); Walter E. Williams, Discrimination and Public Policy, in 1 Selected Affirmative Action Topics in Employment and Business Set-Asides: A Consultation/Hearing of the United States Commission on Civil Rights, MarCh 6-7, 1985, at 9, 18 (1985) (arguing that affirmative 
affirmative action by racial preferences involves racial discrimination and is therefore unjust, and that the Constitution and other laws ought to forbid governmental and private actors from engaging in such immoral practices. Opponents of affirmative action further contend that the victims of racial preferences should be made whole. Thus, for example, when a public university denies admission to a white applicant because of her race, that applicant has been injured by immoral state-sponsored conduct and should be accorded a remedy, such as monetary damages or injunctive relief by the offending state. ${ }^{21}$

The moral argument against affirmative action is also persuasive to the Supreme Court, particularly to the more conservative Justices. These Justices reason that racial discrimination, even for benign purposes, is morally objectionable and that the Constitution forbids the government from engaging in such immoral practices absent a compelling justification. ${ }^{22}$ Remedying the effects of past societal discrimination against blacks, moreover, is not a sufficiently compelling justification for the use of racial preferences. ${ }^{23}$ These Justices further conclude that the victim of unconstitutional discrimination is entitled to a remedy from the responsible sovereign. ${ }^{24}$ Accordingly, when a public university denies admission to a

action is "immoral"); Steve K. Zinnel, Affirmative Action: It's Risky. Costly and Immoral, ENGINEERING News-Rec., Jan. 19, 1998, at 91.

An extensive body of philosophical scholarship addresses the moral implications of affirmative action. See, e.g., Carl Cohen, Naked Racial. Preference (1995); Ronald Dworkin, Taking Rights Seriously 223-39 (1977); Equality and Preferential Treatment (Marshall Cohen et al. eds., 1977); Robert K. Fullinwider, The Reverse Discrimination Controversy: A Moral and Legal analysis (1980); Alan H. Goldman, Justice and Reverse Discrimination (1979); BarRy R. Gross, Discrimination in Reverse: Is Turnabout Fair Play? (1978); Thomas Nagel, MORTAL QUESTIONS 91-105 (1979); Symposium on Reverse Discrimination, 90 ETHICs 81 (1979).

21. See Hopwood v. Texas, 78 F.3d 932, 958-59 (5th Cir. 1996) (declining to issue an injunction, but noting that the district court could, "in its discretion," do so at a future point).

22. See Grutter v. Bollinger, 123 S. Ct. 2325, 2350 (2003) (Thomas, J., concurring in part and dissenting in part); id. at 2348 (Scalia, J., concurring in part and dissenting in part); City of Richmond v. J.A. Croson Co., 488 U.S. 469, 521 (1989) (Scalia, J., concurring in the judgment) (arguing that all racial discrimination, including that in favor of blacks, "is illegal, immoral, unconstitutional, inherently wrong, and destructive of democratic society" and can be justified only by a "social emergency rising to the level of imminent danger to life and limb" (quoting AleXANDER BiCKEL, THE Morality OF CONSENT 133 (1975))); id. at 518 (Kennedy, J., concurring in part and concurring in the judgment) (arguing that affirmative action is in tension with the "moral imperative" of the Equal Protection Clause and is therefore subject to strict scrutiny); Adarand Constructors, Inc. v. Pena, 515 U.S. 200, 240 (1995) (Thomas, J., concurring in part and concurring in the judgment) (reasoning that racial classifications to benefit blacks warrant strict scrutiny because they "undermine the moral basis of the equal protcction principle" and because there is a "moral [and] constitutional equivalence" between such classifications and discrimination against blacks).

23. A majority of the Court rejected remedying societal discrimination as insufficiently compelling to support the use of racial preferences in Croson. See 488 U.S. at 499. The Court reaffirmed this position in Grutter in explaining its approach to racial preferences. See Grutter, $123 \mathrm{~S}$. Ct. at 2336 .

24. See Adarand, 515 U.S. at 239 (Scalia, J., concurring in part and concurring in the judgment) ("Individuals who have been wronged by unlawful racial discrimination should be made whole."); 
white applicant to remedy effects of societal discrimination, the applicant has suffered immoral, and therefore unconstitutional, state action, and is entitled to relief from the state. The Court's doctrine constitutionally prohibits the state and federal governments from using racial preferences to remedy past societal discrimination, and requires that they provide a remedy to victims of such preferences.

The foregoing argument against affirmative action rests on two moral principles. The first principle is that racial discrimination is unjust. The second principle is corrective justice, which posits that one who harms another by wrongful conduct is morally obligated to make amends to the victim. Applied to state-sponsored racial preferences, these principles support the argument that the state is obligated to make amends to the victims of such preferences. These principles, however, also have implications for American society's responsibility for the effects of past societal discrimination against black Americans. To the extent society participated in wrongful discrimination, society is arguably obligated, as a matter of corrective justice, to make amends to the victims thereof. Thus if the socioeconomic disadvantages disproportionately experienced by blacks reflect the effects of societal discrimination, society is arguably obligated to remedy those conditions. A potential moral conflict thus arises between society's obligation to refrain from "reverse" racial discrimination and its obligation to remedy past discrimination. Affirmative action to remedy past discrimination may cause injustice to those disadvantaged by racial preferences. Yet to refrain from remedying past discrimination would leave those injustices uncorrected, a moral wrong in itself according to corrective justice theory. Thus, the moral case against affirmative action also supports a moral case in its favor.

Opponents of affirmative action would likely dispute the existence of any such moral conflict. Some might argue, for example, that no effects of past discrimination exist and, therefore, there is no harm to remedy. Others might argue that whatever effects of past discrimination persist, the responsibility for not overcoming such conditions lies with blacks for failing to take advantage of economic and educational opportunities. Still others could question whether it is fair to call on present members of society to bear the cost of remedying discrimination practiced by past generations. With no moral obligation on the part of society to remedy past discrimination, racial preferences designed to achieve this objective are unjustified and therefore unjust.

This Article explores the moral argument in favor of societal responsibility and the objections just discussed. The Article does not purport to

Croson, 488 U.S. at 518 (Kennedy, J., concurring in part and concurring in the judgment) ("[T]he State has the power to eradicate racial discrimination and its effects in both the public and private sectors, and the absolute duty to do so where those wrongs were caused intentionally by the State itself."). 
establish empirically that effects of past discrimination exist, which very few scholars dispute in any event. ${ }^{25}$ Rather, it explores the normative relationship between these effeets and societal responsibility. This Article is primarily concerned with whether society is responsible, not how such responsibility should be fulfilled. Thus, whether racial preferences or raceneutral policies would be the most effective means for remedying past discrimination is not the central concern. Rather, the concern is the anterior question of whether society bears any responsibility to redress, by whatever means, conditions that result from past discrimination.

To facilitate a constructive discourse, the arguments in this Article draw upon principles that are either accepted by opponents of affirmative action or are widely accepted by American society as relevant to questions of attributing collective responsibility for the harmful effects of wrongful conduct. Useful sources of such principles include well-settled doctrines of law, domestic and international, that incorporate principles of corrective justice. The point of relying on principles endorsed by conservatives is not that all conservatives will accept the implications of applying these principles to a moral defense of affirmative action. The moral argument raises complicated issues, and, moreover, some conservatives may oppose affirmative action for reasons other than its purported immorality, such as economic self-interest or a desire to minimize racial friction. The intent, rather, is to reveal the contradictory implications of claims about the wrongfulness of racial preferences and to persuade more moderate observers that, on balance, America's moral obligation to repair her wrongful history outweighs the moral costs of doing so.

Additionally, this Article's reliance on legal principles does not necessarily imply that our nation is legally obligated to remedy past societal discrimination. The objective, rather, is to defend the plausibility of a moral obligation that American society should assume voluntarily in order to complete its transition to a nation committed to racial equality. ${ }^{26}$ The

25. The widely accepted belief that effects of past discrimination linger does not mean that most scholars accept that society is responsible for such effects. As explained further below, most scholars who oppose racial preferences or other means of remedying past discrimination do so on normative, not empirical, grounds. See infra notcs $99-101$ and accompanying text. 1 is the normative objcctions to societal responsibility that are taken up below.

26. Corrective justice does not unequivocally favor societal responsibility for past discrimination. lndeed, several advocates of govcrnmental remedial programs have criticized corrective justice as inadequatc to support such efforts. See, e.g., Alan Freeman, Antidiscrimination Law: The View from 1989, 64 TUL. L. Rev. 1407 (1990) (criticizing the Supreme Court's "perpetrator model" of antidiscrimination law); Kathleen Sullivan, City of Richmond v. J.A. Croson Co.: The Backlash Against Affirmative Action, 64 TuL. L. REv. 1609, 1613 (1990) (criticizing the Supreme Court's "narrow view of the possible justification for affirmative action" and arguing for race-based programs to redress past discrimination or to serve future distributivc goals); Kathleen Sullivan, Sins of Discrimination: Last Term's Affirmative Action Cases, 100 Harv. L. Rev. 78, 96-97 (1986) (arguing that the Court views affirmative action cases through a sin-based paradigm that invites claims of white 
legal doctrines that incorporate principles of corrective justice provide analytical approaches and illustrations-a heuristic through which to gain some clarity and insight into a most vexing problem. These concepts reflcct the cumulative experience of American society's efforts to attribute responsibility for the injurious effects of culpable human action, and may thus suggest some useful lines of inquiry in assessing societal responsibility for the lingering effects of racial injustice.

The Article begins in Part I with the prima facie case for societal responsibility: that American society wrongfully discriminated against blacks and is morally responsible, as a matter of corrective justice, to remedy its lingering effects. Part II addresses objections to the prima facie case. Part II.A considers whether it is fair to identify current society as the relevant wrongdoer. In particular it looks at whether American society as a whole is responsible for discrimination practiced by some, and whether it is fair to hold current society responsible for discrimination practiced by past society. Part II.B addresses whether blacks today are fairly characterized as victims of past discrimination, given the passage of time and the intervention of personal choices by blacks that may have contributed detrimentally to the condition of black people today. Part III considers some difficulties facing the fulfillment of a societal responsibility for past discrimination. Part III.A considers the difficulty of identifying the scope of the injury to be remedied, that is, the extent to which the condition of blacks would be different today, absent past discrimination, and the problem of identifying the present victims of such discrimination. Finally, Part III.B briefly considers what implications the effects of past discrimination may have for the kinds of policies that would most effectively remedy such effects.

\section{I}

Corrective Racial Justice: The Prima Facie Case for SOCIETAL RESPONSIBILITY

The prima facie case for ascribing responsibility to American society for past discrimination is, in brief, that society participated in wrongful racial discrimination with present harmful effects, and that society is obligated, as a matter of corrective justice, to remedy these harms. Part I.A explains how society wrongfully caused current harmful conditions, and Part I.B explains how corrective justice theory supports an obligation on society's part to remedy such conditions. Part II then addresses potential objections to the argument in this Part.

innocence). As this Article seeks to demonstrate, the corrective justice case is quite complicated, although more plausible than many assume. 


\section{A. Society Wrongfully Caused Harm}

\section{The Nature of the Harm}

Despite the enactment of national antidiscrimination laws in the 1960s, black Americans continue to experience social and economic disadvantage in significant disproportion to their numbers. For example, although whites outnumber blacks six to onc, ${ }^{27}$ more blacks receive welfare than whites, ${ }^{28}$ and blacks are twice as likely to be unemployed, a figure that has remained constant throughout the forty years that such records have been maintained. ${ }^{29}$ Black children are three times more likely than white children to be born outside of marriage (accounting for approximately $70 \%$ of all black births) to a mother who is twice as likely to be a teenager. ${ }^{30}$ Black infants die at two and a half times the rate of white infants, ${ }^{31}$ and those who live are placed in foster care at three times the rate of white children. ${ }^{32}$ Black children are twice as likely to develop serious health problems, including asthma, deafncss, retardation, and learning disabilities, as well as problems resulting from drug or alcohol use during pregnancy. ${ }^{33}$ Black children are nearly four times more likely than white children to grow up in poverty ${ }^{34}$ and among the urban poor, black children are three times morc likely to live in economically segregated low-income neighborhoods. ${ }^{35}$ Blacks live an average of seven years fewer than whites, ${ }^{36}$

27. See Bureau of the Census, U.S. Dep't of Commerce, Statistical abstract of the UNited STATES 1997, at 14, available at http:/www.ccnsus.gov/prod/3/97pubs/97statab/pop.pdf [hereinafter CENSUs] (last visited April 14, 2004).

28. According to one report,

[b]y early 1997 , blacks accounted for $37 \%$ of the nation's welfare caseload, though they are just $13 \%$ of the general population. Hispanic families accounted for $22 \%$ of the welfare rolls, though they are $11 \%$ of the general population. Whites, by contrast, accounted for just $35 \%$ of the rolls, though they are $73 \%$ of the population.

Jason DcParle, Shrinking Welfare Rolls Leave Record High Share of Minorities, N.Y. TIMEs, July 27, 1998, at Al.

29. See andrew Hacker, Two Nations: Black and White, Separate, Hostile, Unequal 108 (Ballantine Books 1995) (1992).

30. See id. at 82 (teenage pregnancy rates); id. at 86 (out-of-marriage birth rates). This Article refers to children born to an unmarried mother as "nonmarital" or "outsidc of marriage" rathcr than the traditional term "illegitimate," a term which unfairly stigmatizes children for the conduct of their parents.

31. See Clinton Plan to Target Disparities in the Health of Whites, Minorities, Buffalo News, Fcb. 22, 1998, at A4.

32. See Judith K. McKenzie, Adoption of Children with Special Needs, 3 FuTURE CHILD. 62, 6869 (1993). According to the U.S. Department of Health and Human Services Administration for Children and Families, 43\% of children in foster care on March 31, 1999, were black, 36\% were white, and $15 \%$ were Hispanic. See Children's Bureau, U.S. Dep't of Health and Human Services, How Many Children Were in Foster Care on March 31, 1999?: 547,000, AFCARS REPORT, Jan. 2000, at http://www.acf.hhs.gov/programs/cb/publications/afcars/rpt0100/ar0100c.htm (last visited Jan. 14, 2003).

33. See HACKER, supra note 29 , at 84 .

34. Id. at 105 .

35. Id. at 105-06. 
and of that life, blacks enjoy eight fewer years of "reasonably good health. ${ }^{" 37}$ Blacks are significantly more likely to suffer or die from serious diseases such as asthma ${ }^{38}$ and, especially, AIDS. ${ }^{39}$

The rates of black involvement with crime and the criminal justice system, both as victims and as perpetrators, are striking. Blacks are twice as likely as whites to be victims of assault and three times as likely to be robbed; black men are seven times as likely to be murdered. ${ }^{40}$ In most of these cases, moreover, the perpetrator is also black. ${ }^{41}$ Indeed, although blacks represent only $12.6 \%$ of the total population, ${ }^{42}$ or one out of eight Americans, they represent a majority of American male prisoners ${ }^{43}$ and are incarcerated at eight times the rate of whites. ${ }^{44}$ In sum, as Alexander Aleinikoff observes:

In almost every important category, blacks as a group are worse off than whites. Compared to whites, blacks have higher rates of unemployment, lower family incomes, lower life expectancy, higher rates of infant mortality, higher rates of crime victimization, and higher rates of teenage pregnancies and single-parent households. Blacks are less likely to go to college, and those who matriculate are less likely to graduate. Blacks are underrepresented

36. See Egypt Freeman, The State of Black Health, HEALTH QUEST, Jan.-Feb. 1998, at 18 (reporting the life expectancy for blacks is 69.6 years as compared to 76.5 years for whites).

37. A National lnstitute for Aging study shows that blacks enjoy fifty-six years of "reasonably good health," eight years less than whites and Hispanics. Peter T. Kilborn, Health Gap Grows, With Black Americans Trailing Whites, Studies Say, N.Y. TIMEs, Jan. 26, 1998, at A16. According to Chris Jennings, then the chief White House adviser on health issues, "huge" disparities remain even when one factors out economic status and education. Id.

38. According to a study by the federal Centers for Disease Control and Prevention, blacks die of asthma at more than twice the rate of whites. See Health Watch News \& Notes: Asthma on the Rise, Atr. J. \& ATL. Const., Apr. 24, 1998, at F3 (reporting that blacks die of asthma at a rate of 38.5 per million, while the rate for whites is 15.1 per million).

39. See Sheryl Gay Stolberg, Eyes Shut, Black America Is Being Ravaged by AIDS, N.Y. TIMES, June 29 , 1998, at Al (reporting that blacks, only $13 \%$ of the U.S. population, account for $57 \%$ of this country's new HIV infections).

40. See HACKER, supra note 29, at 51-52.

41. See id. at 52 .

42. See CENSUS, supra note 27, at 14 (reporting that, in 1995, 12.6\% of Americans wcre black, $73 \%$ white, $10.4 \%$ Hispanic, and $4 \%$ other).

43. See Paul Butler, Affirmative Action and the Criminal Law, 68 U. Colo. L. Rev. 841, 868 n.97 (1997) ("In 1994, for the first time in American history, there were more African American men in prison than white men [in prison].").

44. See Pierre Thomas, Study Suggests Black Male Prison Rate Impinges on Political Process, Wash. Post, Jan. 30, 1997, at A3 (citing a 1995 Sentencing Project report that the incarceration rate of blacks is 7.66 times that of whites). On any given day, one in three black men in their twenties is under the control of the criminal justice system, $i d$., more than the number of black men of all ages in college, see Derrick Bell, RACE, RaCism and AMERICAN LAW 340 n.33 (3d ed. 1992). In contrast, only one in sixteen white males in the same age group is under the control of the criminal justice system. See id. at 340 . The Sentencing Project also reported that one of seven black men (1.46 million of a voting population of I0.4 million) is barred from voting because of a felony conviction. See Thomas, supra. 
in the professions, in the academy, and in the national government. ${ }^{45}$

\section{The Causal Relationship to Historic Discrimination}

What might account for such stark disparities along racial lines? The magnitude and consistency of the disparities suggest that they are not attributable to chance alone. Scholars have accordingly sought to identify factors that plausibly contribute to black disadvantage. Some have documented evidence of the continuing occurrence of racial discrimination. ${ }^{46}$ Others dispute the significance of continuing discrimination in explaining the racial gap, instead emphasizing the tendency of economic deprivation to persist over time within families and communities. ${ }^{47}$ Still other scholars, particularly from the right, claim that the culture of racial minorities, particularly that of blacks, discourages pcrsonal responsibility and selfreliance. ${ }^{48}$

Even assuming that factors such as past economic deprivation, culture, and individual choice account for some of the racial disparities in America today, the question remains why people of a particular race are significantly more likely to experience such conditions or to exercise poor judgment. Most conservatives, moreover, disclaim that race itself biologically affects success ${ }^{49}$ Accordingly, whatever factors immediately account

45. T. Alexander Aleinikoff, A Case for Race-Consciousness, 91 CoLUM. L. REv. 1060, 1065-66 (1991).

46. See A Common Destiny: Blacks and American Society 155 (Gerald David Jaynes \& Robin M. Williams, Jr. eds., 1989) (arguing that statistical findings about racial disparities in attitudes and behaviors suggest a considerable amount of continuing discrimination against blacks); DougLAS $S$. Massey \& Nancy A. Denton, American Apartheid: Segregation and the Making of the UNDERCLASS 8 (1993) (documenting eurrent and substantial housing segregation); T. Alexander Aleinikoff, The Constitution in Context: The Continuing Significance of Racism, 63 U. CoLo. L. REv. 325,328 (1992) (claiming that "the persistence and power of racism ought to be seen as an important part of the social 'context' with which eonstitutional norms regarding equal protection and racial justice interact"); Joe R. Feagin, The Continuing Significance of Race: Antiblack Discrimination in Public Places, 56 AM. Soc. REv. 101 (1991) (describing a study of middle-class African-American experiences with ongoing racism in American society); Deborah C. Malamud, Affirmative Action, Diversity, and the Black Middle Class, 68 U. CoLo. L. Rev. 939, 967 (1997) (arguing that current employment and especially housing discrimination, including in markets for aneillary services sueh as mortgage lending and insurance, are primary sources of inequality for the black middle class).

47. See William Julius Wilson, The Declining Significance of Race: Blacks and Changing American Institutions 144-54 (2d ed. 1980).

48. See sources cited supra note 10.

49. Arguments against affirmative action generally cite the irrelevance of race as a reason why racial preferences are objectionable. See, e.g., Adarand Constructors, Inc. v. Pena, 515 U.S. 200,227 (1995) (arguing that federally sponsored racial preferences should receive strict scrutiny because race is "a group classification long recognized as 'in most cireumstances irrelevant and therefore prohibited"” (quoting Hirabayashi v. United States, 320 U.S. 81, 100 (1943))); City of Richmond v. J.A. Croson Co., 488 U.S. 469, 495 (1989) (arguing that unless state-sponsored racial preferenees are strictly scrutinized, "the 'ultimate goal' of 'eliminat[ing] entirely from governmental decisionmaking such irrelevant factors as a human being's race' will never be achieved" (alteration in original) (quoting Wygant $v$. Jaekson Bd. of Educ., 476 U.S. 267, 320 (1986) (Stevens, J., dissenting)). Not all conservatives dispute 
for America's racial divide, a more complete explanation of its existence requires a historical inquiry.

The most significant experience common to black Americans that has plausibly contributed to their relative disadvantage is a history of racial discrimination. Importantly, such discrimination was supported by American society. For present purposes, society refers to the American people as a nation-a collective people who supported the practice of slavery, and, later, segregation and discrimination through its laws, customs, and practices. Slavery and discrimination were practiced on a pervasive, societywide basis that left blacks vulnerable every day at every turn. Racial subordination was literally the law of the land.

Although any brief account of America's racial history must be inadequate, such a sketch may be useful to explain the present theory on which societal responsibility is based..$^{50}$ Discrimination against blacks in America originated with slavery, although it did not end there. For two and a half centuries, millions of black people were subjected to slavery, an institution that intentionally extinguished the religious, linguistic, and cultural heritage of its victims, routinely splintered families, and mandated illiteracy and ignorance. Moreover, slavery subjected blacks to an ideology of white supremacy, enforced by law and violence, that denied their dignity and humanity. Hundreds of years and countless generations of such treatment guaranteed that, by the time of slavery's abolition, blacks would substantially lack the educational, economic, political, and cultural resources possessed by whites.

American society was deeply implicated in the practice of slavery. The responsibility of the states that practiced slavery is plain. The entire nation, however, also supported slavery not only by tolerating its existence, but by protecting and enforcing the institution through several constitutional provisions. These include an unamendable reservation of the right of states to import slaves until $1808^{51}$ and the Fugitive Slave Clause, a constitutional mandate that slaves who escaped to free states were to remain slaves and be returned to their owners. ${ }^{52}$ Congress and the President chose

the relevance of race, however. See HERR NSTEIN \& MURRAY, supra note 7, at 269-340 (claiming that racial disparities reflect innate differences in cognitive abilities of racial groups). For criticism of Herrnstein and Murray's work, see The Bell Curve Debate: History, Documents, Opinions (Russell Jacoby \& Naomi Glauberman eds., 1995).

50. For a sampling of respected historical works on America's racial history, see generally sources cited infra note 143 .

51. U.S. ConST. art. $1, \S 9$ (providing that Congress shall not prohibit the importation of any persons until 1808); U.S. CoNST. art. V (providing that the importation clause cannot be amended).

52. The Fugitive Slave Clause provides:

No person held to Service or Labour in one State, under the Laws thereof, escaping into another, shall, in Consequence of any Law or Regulation therein, be discharged from such Service or Labour, but shall be delivered up on Claim of the Party to whom such Service or Labour may be due.

U.S. ConsT. art. IV, $\S 2$, cl. 3 . 
to enforce the Fugitive Slave Clause with heavy civil and criminal penalties, ${ }^{53}$ and the Supreme Court repeatedly accorded slavery constitutional protection. ${ }^{54}$ Congress also legally protected slavery in the District of Columbia, known as "the very seat and center of the slave trade," all petitions to prohibit slavery. ${ }^{56}$ As each generation passed, American society's continued support of slavery further implicated the nation in its consequences.

Finally, though the nation, to its credit, formally abolished slavery through the Civil War and the Reconstruction Amendments, it failed to eliminate the legal vestiges of racial oppression or redress the devastating consequences of slavery on those who had suffered under its regime. Had America prohibited all discrimination and provided the necessary resources and opportunities for the four million impoverished and illiterate former slaves to uplift their condition, the effects of slavery might well have dissipated by now. ${ }^{57}$ Instead, however, immediately following the war, southern states established a system of laws or "black codes" that accorded blacks

53. The Fugitive Slave Act of 1793, which was signed by President Washington, was enacted to protcct slave owners' property rights in their human chattel. It imposed a $\$ 500$ penalty, an onerous cost by prevailing monetary values, on any individual interfering with an owner's attempt to recapture an escaped slave, and provided slave owners with tort claims against the offender. See Robert J. Kaczorowski, Fidelity Through History and to It: An Impossible Dream?, 65 FoRdHAM L. REv. 1663, 1673, 1676 (1997). The Fugitive Slave Act of 1850 expanded the federal government's involvement in recapturing fugitive slaves. It extended enforcement responsibility of federal officials to nonjudicial officers, such as postmasters and collectors of customs. The Act imposed heavy fines of $\$ 1,000$, payable to the slave owner, upon any officer who failed to enforce the Act. Id. at 1682 .

54. See, e.g., Scott v. Sandford, 60 U.S. (19 How.) 393 (1856) (holding that blacks could not be U.S. citizens, and invalidating federal law dividing states into slave and free as an unconstitutional deprivation of property); Prigg v. Pennsylvania, 41 U.S. (16 Pet.) 539 (1842) (invalidating state law prohibiting an owner's self-help in returning fugitive slaves); Queen v. Hepburn, 11 U.S. (7 Cranch) 290 (1813) (affirming the lower court's rejcction of a slave's petition for freedom); Scott v. Negro London, 7 U.S. (3 Cranch) 324 (1806) (holding in favor of a slave owner in a dispute over a slave's right to freedom under state law).

55. See John Hope Franklin \& Alfred A. Moss, Jr., From Slavery to Freedom: A History of African AmEricans 115 (7th ed. 1994). The slave trade continued in the District of Columbia until 1850. Id. at 114.

56. Beginning in 1828 , abolitionists repcatedly petitioned the House of Representatives to outlaw slavery in the District of Columbia. The House not only refused to act on the petition, but in 1836 it adopted a rule that all such petitions would automatically be tabled; they did not rescind that rule until 1845. See id. at 177.

57. A number of scholars have made similar observations. See HACKER, supra note 29, at 14 (arguing that "two racial nations" would not exist today, had America fully accepted former slaves as equals following Civil War); Gunnar Myrdal, An American Dilemma: The Negro Problem and MODERN DEMOCRACY (1944) (theorizing that America's failure to provide ex-slaves with an agrarian cconomic base entrenched a racial caste system); ROBINSON, supra note 6, at 202 (discussing Myrdal's theory); Billy J. Tidwell, The Black Report: Charting the Changing Status of African AMERICANS 43 (1997) (arguing that had blacks been accorded substantial economic benefits following the Civil War, such as the forty-acre-and-a-mule formula, there is little doubt that the economic inequality between blacks and other ethnic groups would be markedly reduced today). 
scarcely more rights than they enjoyed during slavery. ${ }^{58}$ Blacks were residentially segregated; required to labor for whites who exercised control over them akin to that of slaveholders; fined, imprisoned, or leased as convict labor for a variety of minor crimes, including vagrancy, "insulting gestures," and violating curfew; and were denied meaningful access to fair judicial process and to the ballot. ${ }^{59}$ In short, as the Supreme Court observed, freedom for the emancipated blacks was severely restricted by "laws which imposed upon the colored race onerous disabilities and burdens, and curtailed their rights in the pursuit of life, liberty, and property to such an extent that their freedom was of little value." Fourteenth Amendment abolished the black codes and blacks achieved admirable political gains in the South during Reconstruction, the withdrawal of federal troops triggered a determined movement by whites to disenfranchise blacks through violence, intimidation, and a variety of voting "qualifications" designed and administered to prevent blacks from voting. ${ }^{61}$ By the turn of the twentieth century, black disenfranchisement was effectively complete. ${ }^{62}$ The process of eliminating blacks from politics was accompanied by the establishment of "Jim Crow" laws that prohibited interracial marriage, segregated blacks in schools and housing, excluded blacks from places of public accommodation, and denied blacks access to a wide range of educational and economic opportunities. ${ }^{63}$

Approximately $90 \%$ of blacks lived in the South throughout the antebellum period and into the twentieth century. ${ }^{64}$ It should be recognized,

58. See Lisa Cardyn, Sexualized Racism/Gendered Violence: Outraging the Body Politic in the Reconstruction South, 100 MicH. L. REV. 675, 801-02 (2002) ("Immediately following the Civil War, southern Iegislatures put their imprimatur on race relations through the passage of a series of 'Black Codes,' statutes that regulated vagrancy, labor, family, and other social relations in an effort to compel blacks to live and work in accordance with whites' changing needs.").

59. See Franklin \& Moss, supra note 55, at 225. Most southern states employed the systcm of "convict leasing" into the twentieth century. Convict leasing was a system in which the state leased convicts, most of them black, to work for persons or companies under often extremely dangerous conditions. See Douglas A. Blackmon, From Alabama's Past, Capitalism and Racism in a Cruel Partnership, WALL ST. J., July 16, 2001, at A1.

60. Slaughter-House Cases, 83 U.S. (16 Wall.) 36, 70 (1872).

61. See Franklin \& Moss, supra note 55, at 254-63. For a detailed account of various methods by which southern states deprived blacks of the franchise, see J. MORGaN Kousser, Colorblind Injustice: Minority Voting Rights and the Undoing of the Second Reconstruction 16-38 (1999). See also Richard H. Pildes, Democracy, Anti-Democracy, and the Canon, 17 Const. Comm. 295 (2001) (examining the disenfranchisement of blacks between 1890 and 1910, and discussing the contributory role of the Supreme Court, which refused to grant relief to blacks disenfranchised on account of their race in Giles v. Harris, 189 U.S. 475 (1903)).

62. See Franklin \& Moss, supra note 55, at 261. The use by all southern states of devices to disenfranchise blacks was so effective that by 1889 Henry W. Grady remarked that "[t]he Negro as a political force has dropped out of serious consideration." Id. at 256.

63. See id. at $261-63$.

64. In $1790,89 \%$ of the black population was enslaved in the southern states, a percentage that remained fairly constant through the Civil War until World War I. See id. at 84 (reporting that $89 \%$ of blacks lived in the South in 1790); Helen Bishop Jenkins, DNA and the Slave-Descendant Nexus: $A$ 
nonetheless, that blacks residing in the North also experienced a substantial degree of racial discrimination. Although northern states abolished slavery by the early nineteenth century, they enacted a variety of racial codes, not unlike those in the South, that severely restricted the rights of blacks in numerous contexts, including education, employment, housing, voting, and intermarriage ${ }^{65}$ Blacks in the North also experienced intimidation and violence, especially those who had recently emigrated from the South. ${ }^{66}$ Following the Civil War, industrial employers and white workers in the North, as in the South, often used violent means to prevent blacks from joining labor organizations and trade unions, leaving blaek workers at the "ragged edge of industry." 67 Blacks in urban areas were segregated into undesirable, congested residential neighborhoods. ${ }^{68}$ Thesc neighborhoods had inadequate housing, schools, municipal services, and recreational facilities. Furthermore, they were plagued by social ills common to urban slums, such as poor health, high mortality, family breakdown, alcoholism and drug abuse, juvenile delinquency, and crime. ${ }^{69}$ By the period following World War II, the black ghetto seemed to have become a permanent feature of America's urban landscape. ${ }^{70}$

The threat and actuality of violence against blacks throughout American history warrants emphasis. Blacks, especially in the South, were subject to police brutality without judicial process, and many accused of

Theoretical Challenge to Traditional Notions of Heirship Jurisprudence, 16 HARV. BLACKLETTER L.J. 211,215 (2000) (stating that $89 \%$ of blacks was slaves in 1860); Michael J. Klarman, Race and the Court in the Progressive Era, 51 VAND. L. REv. 881,898 (1998) (stating that $90 \%$ of blacks resided in the South in 1910). During World War 1 and increasing into the 1960s, huge numbers of blacks migrated North. By 1930 and 1940, respectively, $79 \%$ and $76 \%$ of blacks resided in the South, and by 1960 the black population in the South had fallen to $50 \%$ of blacks nationwide. See Charles E. HaLl, Bureau of The Census, U.S. Dep'T of Commerce, Negroes in the United STATEs, I920-32, at 3 (1935) (estimating that $78.7 \%$ of blacks lived in the South in 1930); MYRDAL, supra note 57, at 183 (estimating that $23.8 \%$ of blacks resided in the North and the West in 1940); Klarman, supra (estimating that $50 \%$ of blacks remained in the South by 1960 ).

65. See David A.J. Richards, Abolitionist Feminism, Moral Slavery, and the Constitution: "On the Same Platform as Human Rights," 18 CARDozo L. REv. 767, 784 (1996) (explaining that northem states practiced discrimination, including segregation in schools and forbidding intermarriage, voting, and travel (citing L. Maria Child, AN ApPeal in Favor of Americans Called Africans 169 (photo. reprint 1968) (1836))); Stuart A. Streichler, Justice Curtis's Dissent in the Dred Scott Case: An Interpretive Study, 24 HASTINGS ConsT. L.Q. 509, 515 (1997) (explaining that the general practice in northern states before the Civil War was to deny free blacks the right to vote).

66. See Franklin \& Moss, supra note 55, at 164-67.

67. See id. at $235,281,310$. The exclusion of blacks from most major labor unions continued through World War l, the postwar period, and the Great Depression. Id. at 341, 381, 401 .

68. See id. at 311. The segregation of blacks into particular sections of town was achieved through a combination of private discrimination and segregation ordinances. $I d$.

69. See id. at $311,407,424$.

70. Id. at $470-71$. 
capital crimes wcre executed after trials where prejudice more than evidence determined the outcome. ${ }^{71}$

Lynching and other forms of extra-judicial violence have also played an integral role in the punishment of blacks ever since their arrival in the New World. ${ }^{72}$ After the abolition of slavery, there was an increase in incidents of lynching by whites who believed, erroneously, that the judicial process would protect blacks accused of committing crimes. In the last sixteen years of the nineteenth century, whites committed more than 2,500 lynchings, the great majority of which involved black victims. ${ }^{73}$ An additional 1,100 lynchings occurred between the turn of the century and the outbreak of World War I. ${ }^{74}$ Although lynchings were more common in the South, they also occurred in the North and, particularly, in the Midwest. ${ }^{75}$

After World War I, whites escalated lynching and mob violence against blacks in an effort to check expectations of equal citizenship held by returning black soldiers. ${ }^{76}$ In the first year following the war, more than seventy blacks were lynched, including ten soldiers in uniform. ${ }^{77}$ This rise in racist violence accompanied the growth of the $\mathrm{Ku}$ Klux Klan, which members revived in the South in 1915. The Klan grew to include over 100,000 members within a year of the end of World War I, with a presence that included many New England and Midwestern states. ${ }^{78}$ The Klan's substantial political influence, moreover, often rcquired political candidates to join or support the Klan in order to win public office. ${ }^{79}$ In addition to lynching, race riots and mob violence erupted periodically across the country in which most people injured or killed were black. ${ }^{80}$ White hostility toward blacks in the North increased as blacks migrated from the South. ${ }^{81}$ Indeed, gang violence and riots against blacks were as vicious in the North as in the South. ${ }^{82}$ Overt violence against blacks remained common until the $1960 \mathrm{~s}^{83}$ The ever-present threat that any asscrtion of rights or interests would be met with brutal and often fatal reprisals imposed powerful constraints upon the ability of blacks to improve their condition. As Andrew Hacker observes:

71. See, e.g., Dickson D. BRuce, Violence and Culture in the ANTEbellum South (1979); Stewart E. Tolnay \& E.M. Beck, A Festival of Violence: An Analysis of Southern LYNCHINGS, 1882-1930 (1995).

72. FrankLIN \& Moss, supra note 55, at 312.

73. Id.

74. Id.

75. Id.

76. See id. at 347.

77. Id. at 348 .

78. Id. at $347-48$.

79. Id. at 348 .

80. Id. at $312-17$.

81. Id. at 315 .

82. Id.

83. See generally id. at $312-54,469,509$. 
Overarching it all was the terror, with white police and prosecutors and judges possessing all but total power over black lives. Not to mention the lynchings by white mobs, with victims even chosen at random, to remind all blacks of what could happen to them if they did not remain compliant and submissive. ${ }^{84}$

Thus, for the hundred years following emancipation, America not only failed to redress the effects of slavery, but it permitted and engaged in the continuing subjugation of black people. The constant onslaught of degrading, dehumanizing treatment from all quarters of society served to deny blacks any meaningful opportunity to become educated, develop lucrative skills, pursue entrepreneurial ventures, exercise political power, or live free of state or state-tolerated violence and lynching. ${ }^{85}$ Laws and customs in the North and South that effectively prohibited blacks and whites from learning together, ${ }^{86}$ living together, ${ }^{87}$ and loving each other ${ }^{88}$ further guaranteed the continued disadvantage of the black race. By the time of the Kerner Commission report in 1969, the condition of blacks was so inferior to that of whites as to justify the report's characterization of America as "moving toward two societies, one black, one white-separate and unequal." 89

Although, laudably, America enacted national antidiscrimination laws in the 1960s, wide disparities between blacks and whites persist across virtually every indicator of social and economic well-being. ${ }^{90}$ lndeed, as the

84. HACKER, supra note 29, at 53.

85. Summing up the experience of black Americans from emancipation until the 1960s, Hacker observes:

For almost a century after the abolition of slavery, America's black population subsisted under a system of controls. In the South, physical force was blatant and unabashed. The whims of a sheriff, an employer, even the driver of a bus, could hold black lives in thrall. In the North, intimidation and oppression were less explicit but nonetheless real.

Id. at 20 .

86. See Milliken v. Bradley, 418 U.S. 717 (1974) (upholding findings of intentional segregation in Detroit schools while invalidating an interdistrict busing remedy); Brown v. Bd. of Educ., 347 U.S. 483 (1954) (invalidating segregation in public schools in Virginia, Delaware, South Carolina, and Kansas); Bolling v. Sharpe, 347 U.S. 497 (1954) (invalidating segregated public schools in the District of Columbia).

87. See Shelley v. Kraemer, 334 U.S. 1 (1948) (invalidating racially restrictive covenants).

88. See Loving v. Virginia, 388 U.S. 1 (1967) (invalidating state antimiscegenation law, similar versions of which existed in sixteen states).

89. See Report of the National Advisory Commission on Civil Disorders 1 (1968). The Kerner Commission was a distinguished panel appointed by President Lyndon Johnson to investigate the causes of the urban riots of 1965-67. Although President Johnson established the commission in 1968, it did not issue its final report until December 1969.

90. See supra notes 27-45 and accompanying text; see also A Common Destiny, supra note 46, at 6 (observing that "[s]ince the early 1970s, the economic status of blacks relative to whites has, on average, stagnated or deteriorated"); Alex M. Johnson, Jr., Bid Whist, Tonk, and United States v. Fordice: Why Integrationism Fails African-Americans Again, 81 CALIF. L. REv. 1401, 1427 (1993) (observing that "the plight of African-Americans has not measurably improved in the two generations since Brown"); Magee, supra note 6, at $876 \mathrm{n} .51$ (noting that "the proportion of African-Americans in poverty relative to other Americans has remained unchanged since the civil rights legislation of 1965"); 
twentieth century came to a close, the condition of many poor blacks had worsened in many respects. As John Hope Franklin and Alfred Moss observe:

The last two decades of the twentieth century saw heightened economic deprivation and social problems in poor black communities: chronic unemployment, rampant violence, drug addiction, HIV infection and AIDS, soaring homicide rates for young black males, high levels of illegitimate births to young black females, and public school systems overwhelmed by all these problems. $^{91}$

Given the history of discrimination against blacks in this country, the persistence of substantial disparities between whites and blacks is not surprising. ${ }^{92}$ Such disparities reflect, at least to some degree, effects of past discrimination. That is, these conditions would not exist to the same extent but for America's history of racial discrimination against black Americans. Even the widening disparity between blacks and whites in recent years with respect to certain social problems appears to be linked to conditions existing during segregation. Consider, for example, that between 1950 and 1993, the gap between black and white households headed by single women increased from just under $12 \%$ to almost $40 \% .{ }^{93}$ Read in context,

Michael H. Cottman, U.S. Racial Gap Persists: 20 Years After Kerner Report, Panel Finds Blacks' Progress Lags, Newsday (Long Island, N.Y.), July 28, 1989, at 7 (noting that the National Research Council study "found that blacks still lag far behind whites in economic, social, political and educational status" and that improvements have slowed dramatically since the 1970s).

91. Franklin \& Moss, supra note 55, at 551-52.

92. Indeed, one may reasonably question whether racial disparities should be expected to have narrowed at all, let alone disappeared. Once black people have been subjugated in an uneducated, unskilled existence over numerous generations, it could fairly be asked why they should be able to improve their condition more effectively than whites. As Randall Robinson observes:

No nation can enslave a race of people for hundreds of years, set them free bedraggled and penniless, pit them, without assistance in a hostile environment, against privileged victimizers, and then reasonably expect the gap between the heirs of the two groups to narrow. Lines, begun parallel and left alone, can never touch.

RoBinson, supra note 6 , at 74 . One might even expect some disparities to have widened given the tendency of certain social ills to exacerbate themselvcs from one generation to the next. It is not the purpose of this Article to debate whether some closing or widening of the racial gap should have been expected by now, but simply to observe that the persistence of such substantial disparities is plausibly caused in some part by past societal discrimination.

93. The table below shows the percentages of black and white female-headed households from 1950 to 1993, and the multiple of black to white households at each measurement date. The focus is on families without a husband and with children under eighteen years old:

HOUSEHOLDS HEADED BY WOMEN: 1950-1993

\begin{tabular}{llll} 
Year & Black & White & Black Multiple \\
\hline 1950 & $17.2 \%$ & $5.3 \%$ & 3.2 \\
1960 & $24.4 \%$ & $7.3 \%$ & 3.3 \\
1970 & $34.5 \%$ & $9.6 \%$ & 3.6 \\
1980 & $45.9 \%$ & $13.2 \%$ & 3.5 \\
1993 & $58.4 \%$ & $18.7 \%$ & 3.1
\end{tabular}

See HACKER, supra note 29 , at 74. 
however, this increase does not appear to signify a greater rate of family breakdown among blacks compared to whites. Throughout this period, the ratio of black to white female-headed households has remained constant at just over three to one. ${ }^{94}$ The rate of increase in both groups has thus been the same since segregation. These data suggest that the apparent widening between the races actually reflects comparable reactions within both groups to common cultural trends. The widening in absolute terms simply reflects the disparity that existed during and as a likely product of segregation.

Similarly, consider the rate of out-of-marriage births of blacks compared to whites, a statistic often cited as evidence that the deterioration of familial and sexual norms is a phenomenon of black culture. Undoubtedly, the explosive rate of such births among blacks, approximating $70 \%$ of all black births, contrasts starkly with less than $20 \%$ of white births. ${ }^{95}$ Nonetheless, the ratio of black to white nonmarital birth rates has not increased and in fact has declined since 1950 to less than half what it was then. ${ }^{96}$ "Put another way," Hacker observes, "even though the number of births to unwed black women has ascended to an all-time high, white births outside of marriage have been climbing at an even faster rate."97 Accordingly, the current disparity in nonmarital birth rates between blacks and whitcs cxists only because a disparity already existed before the abolition of segregation.

Although a causal connection between racial disparities and past discrimination seems probable, if not obvious, this section has not conclusively proven that such a connection exists. Historical causes of such a unique and long-standing character are not susceptible to the kinds of controlled testing and comparisons necessary to identify causal relationships with scientific certainty. There are, however, reasons to assume that a

94. Id. In fact, the multiple of black to white households was roughly the same in 1950 as in 1993, 3.2 and 3.1 respectively. There was a mild increase in the multiple before 1970 and a corresponding decrease after 1970. Thus, if anything, the rate of marital breakdown for blacks has decreased, relative to whites, in the decades after the end of legal segregation, which lends support to the claim that the causes of family breakdown among blacks today antedate the civil rights laws of the 1960s.

95. The table below shows the percentage of out-of-marriage births among blacks and among whites from 1950 to 1992 , and the multiple of black to white percentages at each measurement date. BIRTHS OUT OF WEDLOCK: $1950-1992$

\begin{tabular}{llll} 
Year & Black & White & Black Multiple \\
\hline 1950 & $16.8 \%$ & $1.7 \%$ & 9.9 \\
1960 & $21.6 \%$ & $2.3 \%$ & 9.4 \\
1970 & $37.6 \%$ & $5.7 \%$ & 6.6 \\
1980 & $56.4 \%$ & $9.3 \%$ & 6.1 \\
1992 & $68.3 \%$ & $18.5 \%$ & 3.7
\end{tabular}

See HACKER, supra note 29 , at 87.

96. See id.

97. Id. 
causal relationship exists. First, the causal claim at issue is limited: stark disparities between blacks and whites are an actual result of past discrimination in the sense that, had slavery and discrimination not been legally protected or had they been abolished and remedied substantially sooner, the disparities today would not be as great. The point for present purposes is not that the causal relationship necessarily establishes societal responsibility, but merely that regardless of the more immediate causes that may be responsible for black disadvantage (such as black culture and choice), past discrimination also plays a historical causal role. ${ }^{98}$

Indeed, it should be emphasized that most conservatives accept or are willing to assume a causal connection between black disadvantage and past discrimination, although their rhetoric sometimes suggests otherwise. Close inspection of conservative writings reveals that the essence of their claim that blacks, not society, are responsible for their condition is normative, not empirical. ${ }^{99}$ Most recognize that historical causes, including racial oppression, have contributed to the development of self-destructive behavior among blacks. They argue, however, that responsibility for such behavior should be limited to the black people who directly engage in that behavior today. ${ }^{100}$ The next Part addresses such arguments. Conservatives on the Supreme Court also acknowledge the effects of past societal discrimination, but reason that such effects are too "amorphous" to justify race-based preferences. ${ }^{101}$ Part III responds to this argument.

The remainder of this Article therefore presumes that effects of past discrimination exist and considers whether current society is morally obligated to remedy them.

98. Indeed, black culture itself has almost certainly developed in part as a response to discrimination or its effects, particularly because slavery stripped blacks of the culture they had before enslavement. Those who would require scientific proof that disparities between blacks and whites would not be just as great and one-sided if blacks had not been discriminated against are unlikely ever to recognize the possibility of societal responsibility for America's discriminatory history.

99. For example, Dinesh D'Souza, an ardent opponent of affirmative action, contends that black culture is to blame for the perpetuation of black disadvantage, yet he acknowledges that the culturaI shortcomings he identifies developed as a result of historical discrimination. D'Souza, supra note 10, at 791 ("African-Americans as a group have developed a culture that represents an intelligent, sophisticated, and legitimate adaptation to historical oppression. Unfortunately, it is also a culture that, in many important and definable respects, is a liability today." (citation omitted)).

I00. Id.

I01. See, e.g., City of Richmond v. J.A. Croson Co., 488 U.S. 469, 499 (I989) ("While there is no doubt that the sorry history of both private and public discrimination in this country has contributed to a lack of opportunities for black entrepreneurs, this observation, standing alone, cannot justify a rigid racial quota in the awarding of public contracts in Richmond, Virginia."); id. at 528 (Scalia, J., concurring in the judgment) ("Since blacks have been disproportionately disadvantaged by racial discrimination, any race-neutral remedial program aimed at the disadvantaged as such will have a disproportionately beneficial impact on blacks."); id. at 499 (explaining that remedying societal discrimination is too "amorphous" an objective to justify the use of racial preferences). 


\section{B. Society's Obligation to Remedy the Harm}

Corrective justice theory supports ascribing responsibility to society for the effects of past societal discrimination. For the purposes of this Article, corrective justice does not mean a complicated account of moral responsibility, but rather something quite basic: one who causes harm to another by wrongful conduct is morally obligated to compensate the victim or otherwise remedy the harm. ${ }^{102}$ To the extent that American society's wrongful participation in racial discrimination continues to have effects today, corrective justice suggests a moral obligation on society's part to remedy such effects.

I rely on corrective justice as a basis for societal responsibility for a number of reasons. In keeping with my effort to employ principles acceptable to conservatives, it is notable that they rely upon corrective justice in arguing that the victims of racial preferences are entitled to redress. I too find corrective justice a persuasive theory of moral responsibility. The obligation of one who harms another through wrongful conduct to make amends to his victim seems to follow from the most basic notions of justice. That justice requires rectification of injustice, the righting of a wrong, is intuitive to most people. I also agree with conscrvatives that corrective justice is plausibly implicated by racial discrimination. The source of moral obligation under corrective justice theory is unjust conduct that causes harm. To the extent racial discrimination is morally objectionable, its harmful consequences potentially serve as a basis of moral responsibility. Constitutional and statutory law imposing liability for racial discrimination are commonly - and legitimately-justified on grounds of corrective justice. Finally, corrective justice theory has deep roots in the moral and legal traditions of American society, such as criminal ${ }^{103}$ and tort law, ${ }^{104}$ as well as in the cultural norms that govern social relations. Indeed, the obligation to repair a wrong is a principle reflected in every legal system in the

102. The classic account of corrective justice theory comes from Aristotle. See ARISTOTLE, Nicomachean Ethics 120-23 (Martin Oswald ed. \& trans., Bobbs-Merrill 1962) (1911). For a eontemporary proponent of corrective justice as a basis of moral responsibility, see JUDITH JARVIS Thomson, Rights, Restitution, ANd Risk: Essays in Moral Theory 149 (1986) ("It may even be granted that if we have wronged $A$, we must make amends, that justice requires it, and that a failure to make amends is not merely callousness, but injustice.").

103. See Herbert Morris, On Guilt and InNocence 34 (1976) (discussing corrective justice foundations of retributivism).

104. See generally Larry A. Alexander, Causation and Corrective Justice: Does Tort Law Make Sense?, 6 L. \& PHIL. 1 (1987); Jules L. Coleman, Tort Law and the Demands of Corrective Justice, 67 1ND. L.J. 349 (1992); David G. Owen, The Moral Foundations of Products Liability Law: Toward First Principles, 68 Notre Dame L. Rev. 427 (1993); Richard A. Posner, The Concept of Corrective Justice in Recent Theories of Tort Law, 10 J. LEGAL STUD. 187 (1981); Emest J. Weinrib, Corrective Justice, 77 Jowa L. Rev. 403 (1992); Catharine Pierce Wells, Tort Law as Corrective Justice: A Pragmatic Justification for Jury Adjudication, 88 MiCH. L. REv. 2348 (1990). 
world. ${ }^{105}$ The substantial consensus regarding the legitimacy of corrective justice theory not only supports its use as a basis of moral responsibility, but also provides a rich source of experience regarding how to apply the theory to circumstances involving collective wrongdoing and consequential harm.

Although corrective justice theory is basic in structure, a brief elaboration may be useful before considering its implications for societal discrimination. According to corrective justice theory, one who causes a harm that disrupts a just distribution of rights, resources, or opportunities has an obligation to redress the harm caused and thereby restore the just distribution. Summarizing Aristotle, Robert Cooter explains:

[E]ach type of society has its own principle of wealth distribution. Thus, a democratic society favors an equal distribution; in contrast, an aristocratic society favors the principle that the best should have more. Once a society's conception of the just distribution is achieved, a person who disrupts it does an injustice that must be corrected, according to this theory, by paying compensation. ${ }^{106}$

Applied to the context of societal discrimination, a racially just society, that is, one committed to racial equality, is one in which racial discrimination does not affect the distribution of people's rights, resources, or opportunities. As argued in Part I.A, whatever the immediate causes of the stark disparities between blacks and whites, such disparities would probably not exist to the extent they do today had blacks not been discriminated against en masse for so many generations. If American society disrupted the racially just distribution of black people's rights, resources, and opportunities by discriminating on the basis of race, then as a matter of corrective justice, society has a prima facie obligation to redress the harmful effects of that discrimination.

The nature of society's obligation is not simply that society has inherited a fixed debt owed by past society to past generations. Rather, society has a continuing duty to present generations of people who experience fresh injuries from conditions caused by past discrimination. Nor is the obligation owed to all black people as a group or "creditor race," but rather it is owed to those individual black people whose lives are disadvantaged by past discrimination. ${ }^{107}$ Each American child born today into a life worse

105. See Anthony D'Amato \& Kirsten Engel, State Responsibility for the Exportation of Nuclear Power Technology, 74 VA. L. REv. 1011, 1047 (1988) (observing that every legal system in the world recognizes the principle that one who harms another has a duty to compensate the injured party); Restatement (Third) of Foreign Relations Law of the United States $\$ 102(1)$ (1987) [hereinafter RESTATEMENT OF FOREIGN RELATIONS] (explaining that general principles common to the major legal systems of the world include the obligation to repair a wrong).

106. Robert Cooter, Torts as the Union of Liberty and Efficiency: An Essay on Causation, 63 ChI.-Kent L. Rev. 523, 546 (1987).

107. Justice Scalia coined the term "creditor race." See Adarand Constructors, Inc. v. Pena, 515 U.S. 200, 239 (1995) (Scalia, J., concurring in part and concurring in the judgment) ("Individuals who 
off than it would be had society not practiced slavery, segregation, and othcr discrimination, or had society adequately remedied their effects, is a new individual victim of societal discrimination. Society's persistent failures to redress adequately conditions that predictably perpetuate, and often worsen, the effects of such past racial injustices, are recurring wrongs that create new remedial obligations. Until society fulfills its responsibility to address this racial injustice, its moral obligation shall remain unabated.

The basic structure of the foregoing argument parallels arguments by white people, such as the plaintiffs who prevailed against the University of Michigan, who claim they were harmed by racial preferences and are therefore entitled to relief. ${ }^{108}$ To the extent their opportunities have been impaired by the university's use of racial preferences in favor of the benefited minorities, corrective justice theory supports the argument that the State of Michigan is obligated to make them whole. Similarly, regarding a societal obligation toward blacks harmed by past discrimination, to the extent their opportunities have been impaired by society's use of racial preferences in favor of whites, corrective justice theory supports the argument that American society is obligated to make them whole.

There are, of course, theories in addition to corrective justice that support ameliorating conditions disproportionately suffered by black Americans. Civil rights efforts to eliminate ongoing racial discrimination against black people are justified simply because such discrimination is immoral and harmful. American society has committed itself expressly to this position. ${ }^{109}$ Restitutionary theory might also justify enhancing the

have been wronged by unlawful racial discrimination should be made whole; but under our Constitution there ean be no such thing as either a creditor or a debtor race."). Scalia's position accords with the emphasis conservatives often place on treating people as individuals rather than as members of groups. For conservatives, racial group classifications are problematic to the extent they may erroncously presume commonality among individuals simply because of their race or, in constitutional terms, to the extent such classifications may bc a poor "fit" with the traits for which race is used as a proxy. Despite rhetoric to the contrary, however, conservatives do not oppose racial group classifications per se. In Gratz v. Bollinger, for example, the conservative-backed plaintiffs challenging affirmative action self-identified as members of a certified class comprising "those individuals who applied for and were not granted admission to the [University of Michigan] . . . and who are members of those racial or ethnic groups, ineluding Caucasian, that defendants treatcd less favorably on the basis of race." 123 S. Ct. 2411,2418 (2003). This Article is likewise concemed with a racially identifiable class of victimized individuals, namely, those black individuals whosc lives are worse off than they would be absent Ameriea's history of racial discrimination. Admittedly, the shorthand I sometimes use for this victim-class-"black people" or "black Americans"-is an imperfect proxy, but it should be understood as only a shorthand. Moreover, as argued in Part III.B, below, that not all black people who might benefit from remedial policies are necessarily victims of past discrimination does not relieve America of her obligation to pursue such policies for the benefit of those actually harmed by her diseriminatory history.

108. See supra note 107 (describing the certified class in Gratz v. Bollinger, I23 S. Ct. 2411, 2418 (2003)).

109. See Civil Rights Act of 1964, Pub. L. No. 88-352, 78 Stat. 241 (codified as amended in scattered sections of 28 and 42 U.S.C.) (establishing an Act to enforce voting rights, eliminate 
resources and opportunities of blacks, as a disgorgement of America's "unjust enrichment" gained from the exploitation of blacks." Alternatively, addressing the social and economic disadvantages experienced by blacks may be warranted as a matter of distributive justice, which arguably requires that any individual or group be given certain minimum opportunities or means of subsistence regardless of the cause of their disadvantage. ${ }^{111}$ Whether or not conservatives believe America is obligated to its black citizens by these other theories, corrective justice theory, which they endorse in the affirmative action debate, suggests that America has a prima facie responsibility to make amends for its historical protection of slavery and racial caste.

II

\section{Objections to the Prima facie Case: Problems of INTERGENERATIONAL RESPONSIBILITY}

This Part considers potential objections to the case set forth above for ascribing responsibility to present society for past discrimination. As described in Part I, the elements of a claim based on corrective justice are that one has, by wrongful conduct, caused harm to another. Part II.A examines the initial elements of the case, specifically discussing whether the wrongful conduct described in Part 1 may be attributed to present society. Part II.B considers whether, assuming a causal connection between present conditions and past discrimination, the intervention of black people's

discrimination in public accommodations, and create the Commission on Equal Employment Opportunity, among other purposes).

110. The restitutionary theory of unjust enrichment provides that one who gains from wrongful conduct against another is obligated to transfer the gain to the victim. The difference between unjust enrichment and the compensatory version of corrective justice theory advanced herein is that the former determines the magnitude of the wrongdoer's obligation by the extent of his wrongful gain, whereas the latter looks to the extent of the victim's loss. See Douglas Laycock, The Scope and Significance of Restitution, 67 TEx. L. Rev. 1277, 1282-83 (1989) (explaining that restitution is properly limited to wrongful gain or restoration of specific property, as distinct from compensation for the victim's loss). Unjust enrichment is thus based on wrongful gain, corrective justice on wrongful loss. It is possible for a wrongdoer to have a greater obligation under a theory of unjust enrichment than corrective justice, as where the wrongdoer reaps a profit from his misconduct greater than the injury caused to the victim, or a lesser obligation, as where the injury to the victim is not accompanied by a comparable gain to the wrongdoer. See id. at 1287 (explaining that the victim's loss may be greater than, less than, or equal to the wrongdoer's gain). With respect to a societal obligation for past discrimination, a theory of unjust enrichment would rely on the extent to which American society has gained from its mistreatment of blacks, rather than the extent to which blacks are worse off. Such a theory is certainly plausible, but its evaluation lies outside the scope of this Article.

111. See Owen M. Fiss, Groups and the Equal Protection Clause, 5 PHIL. \& PuB. AfF. 107, 151 (1976) (advocating a redistributive "group disadvantaging principle" requiring relief for groups, such as blacks, that constitute a "perpetual underclass," regardless of the historical causes of their status); Vemon Van Dyke, Justice as Fairness: For Groups?, 69 AM. Pol. SCI. Rev. 607 (1975) (reviewing John RAwLS, A THEORY OF JUSTICE (1971)) (arguing that John Rawls's principles of equality may support distributive justice among social groups). 
choices and the passage of time should nonetheless serve to absolve society of responsibility.

\section{A. Identifying Current Society with Past Discrimination}

Conservatives may raise a number of objections to the claim that American society today is implicated in the wrongful discrimination practiced by past generations. First, society's past discrimination was arguably not wrongful in light of prevailing norms. That is, it may be unfair to blame society, in hindsight, for practices that were legal at the time and widely perceived as morally permissible. Second, it is arguably unfair to attribute responsibility to the nation as a whole for the slavery and discrimination practiced by only some private and governmental actors. Third, whatever responsibility past society bore for the discrimination practiced under its watch, present society did not participate in such discrimination. These objections suggest the difficulties in ascribing responsibility to present society for the practices of times past. Although such concerns may well be dispositive to some, the following sections suggest reasons to remain open to the possibility of intergenerational, collective responsibility.

\section{The Wrongfulness of Slavery and Segregation}

The first objection is that, because past society believed discrimination to be acceptablc, it would be unfair to blame society for acting wrongfully. During the period in which state and federal laws sanctioned slavery and discrimination, a majority of Americans presumably believed these practices were not immoral, at least not intolerably so. To hold now, in hindsight, that society committed immoral acts would impose on society an obligation based on conduct that has only become widely accepted as immoral after its occurrence. It is arguably unfair to blame society based on moral standards not yet established at the time of the purportcd wrongdoing. As corrective justice is premised on injustice, ${ }^{112}$ the claim that there was no injustice strikes at the heart of the case for societal responsibility.

While this objection has some intuitive force, a number of observations undermine it. First, it cannot necessarily be inferred from the legalization of slavery that a majority of the population, much less the entire nation, believed the institution morally justified. Blacks, who comprised a substantial, disenfranchised portion of the population, ${ }^{113}$ did not support slavery. Were the views and votes of blacks on slavery counted, a majority

112. See Posner, supra note 104 , at 190 (observing that the duty to rectify under corrective justice theory requires not only an injury, but an injury occasioned by wrongdoing).

113. In 1790 , blacks numbered slightly more than 750,000 of the nearly four million inhabitants of the United States, comprising almost $20 \%$ of the total population. See FrankLIN \& Moss, supra note 55 , at 559 tbl.11. By 1860 , the black population had grown to nearly 4.5 million, although its percentage of the total population had declined to just over $14 \%$. Id. 
of the population may have opposed slavery. Consider also that blacks comprised a particularly significant percentage of the population in those states that practiced slavery. ${ }^{114}$ Had blacks been able to vote, these states or Congress might have abolished slavery well before the Civil War.

Second, even if a majority of whites at least tacitly acquiesced in slavery, the nation had considerable reason to believc that its protection of and participation in the institution was morally problematic. ${ }^{115}$ Throughout the slavery period, abolitionist whites and blacks publicly emphasized the wrongfulness of slavery and racial subordination and the inconsistency of these practices with the egalitarian principles upon which the nation was founded. ${ }^{116}$ Indeed, the Founders' recognition that blacks were "Persons" and that slavery raised serious moral questions is reflected in their studious avoidance of any reference to "slave" or "slavery" in the Constitution,

114. Throughout the slavery period of the United States, approximately $90 \%$ of the black population resided in the South. See supra note 64 . The result was that blacks comprised a significant percentage of the total population in slave-holding states. In 1790, the black population in the South was slightly more than half the size of the southern white population. 1 BUREAU OF THE CENSUS, U.S. Dep't of Commerce, Historical Statistics of the United States, Colonial Times to i97o, at 22 (1975). By 1860, the slave population in the South, numbering almost four million, was approximately half the size of the southern white population. See FrankLIN \& Moss, supra note 55, at 123. The percentage of blacks was even higher in particular slave states. In 1750, for example, the number of blacks in Virginia approached the number of whites, and the number of blacks in South Carolina actually exceeded the number of whites. Id. at 65 tbl.1. By 1840, in the Alabama-Mississippi region, the black population, mostly slave, was approximately as large as the white population. See id. at 111 .

115. As I argue below in Part II.A.1, conservative claims that racial discrimination, including affirmative action, is inherently immoral preelude the defense of slavery's morality on grounds of societal acceptance. Nonetheless, even assuming societal ignorance of moral law should sometimes serve as an excuse for wrongdoing, the moral controversy surrounding slavery during its practice precludes a societal claim of unfair surprise in learning of slavery's unjust character. An analogy to the criminal law would be the claim that ignorance of law should immunize a defendant from criminal blame. Courts rarely recognize such a defense, except if at all, in cases where no reasonable, lawabiding person would expect that the prohibited conduct violated the law. See, e.g., Lambert v. Califomia, 355 U.S. 225, 229 (1957) (overturning a conviction in part on the ground the defendant had no reason to know of the law's requirements). American society did have reason to know that slavery was wrong.

116. Opposition to slavery came from many quarters after its introduction into the New World, opposition which, importantly, heightened during the Revolutionary and Founding periods. See FRANKLIN \& Moss, supra notc 55, at 65, 79-81. Beginning in 1766, for example, and continuing throughout the War of Independence, scores of blacks introduced petitions in eolonial courts and legislatures seeking freedom from bondage, while the colonists, with black participation, fought for political freedom from Britain. Id. at 79. A number of white leaders of considerable stature, including Benjamin Franklin and Noah Webster, also spoke out against slavery. Numerous manumission and antislavery societies were formed during the Revolutionary period and became even more widespread after the war. Id. at 80 . The Constitutional Convention itself included a fierce debate over the question of slavery and the slave trade, the resolution of which resulted in the constitutional protection of the institution. Id. at 81-83. The antislavery movement continued into the nineteenth century, intensifying by the 1830 s in the North and West. Id. at 171-88. Indeed, there was also considerable southern sentiment against slavery during the colonial and early national periods. $I d$. at 188 . 
despite provisions squarely respecting the institution and the participants therein. ${ }^{117}$

Third, although the rights of blacks to be respected as persons under the Constitution may have been in doubt before emancipation, the Civil War Amendments formally guaranteed blacks citizenship, as well as civil and political equality. ${ }^{118}$ The societal discrimination perpetrated against blacks for another century thereafter was thus undertaken not only against a background of moral notice, but in violation of the letter of the Constitution. Society thus cannot plausibly claim unfair surprise at being charged with having violated the moral rights of blacks for the hundred years following the Civil War.

Fourth, that a majority of society believed slavery and discrimination were morally permissible only negates society's responsibility if the morality of racial oppression depends solely on the views of the society that practices it. Such a position would immunize a societal practice against moral criticism whenever the society that supports the practice believes it morally tolerable. The Nazi Holocaust would not be wrong, for example, if German society endorsed or acquiesced in it. ${ }^{119}$ Such a defense would hardly negate the evil character of that murderous episode. Moreover, present-day opponents of affirmative action do not rely for the validity of their position on current society agreeing that such policies are wrong. Rather, they contend that racial preferences violate fundamental principles of colorblind equality - principles that were violated by past discrimination against blacks and which ought not again be violated by present discrimination against whites.

Finally, if the legal toleration of a practice protects it from moral condemnation, then affirmative action policies cannot be judged immoral. Forty-seven of fifty states permit affirmative action under state law, and the federal government permits, indeed requires, affirmative action in a variety

117. See Fugitive Slave Clause, U.S. Const. art. IV, $\S 2, \mathrm{cl} .3$ (requiring that any "Person held to Service or Labour" who escapes to another state shall be returned to "the Party to whom such Service or Labour may be due"); Importation Clause, U.S. CoNST. art. I, $\S 9, \mathrm{cl}$. 1 (providing that the "Importation of such Persons as any of the States now existing shall think proper to admit" shall not be prohibited by Congress prior to 1808); Apportionment Clause, U.S. ConST. art. I, § 2, cl. 3 (providing that apportionment of representatives among the states "shall be determined by adding to the whole Number of free Pcrsons . . . three fifths of all other Persons"); Herbert J. Storing, Slavery and the Moral Foundations of the American Republic, in SLAvery AND ITS CONSEQUences: THe Constitution, Equality, AND RacE 45, 54-56 (Robert A. Goldwin \& Art Kaufman eds., 1988).

118. See U.S. ConST. amend. XIII (abolishing slavery); U.S. ConST. amend. XIV, § I (guaranteeing citizenship to all persons bom in the United States, guaranteeing privileges and immunities to all U.S. citizens, and guaranteeing due process and equal protection rights to all persons); U.S. Const. amend. XV (guaranteeing that the right of U.S. citizens to vote sball not be denied or abridged on account of race, color, or previous condition of servitude)

119. See generally Kurt Schwerin, German Compensation for Victims of Nazi Persecution, 67 Nw. U. L. REV. 479, 481 (1972) (surveying the history of German reparations and describing the Holocaust as "utter brutality," "unprecedented savagery," and "a disruption of all normal human ties"). 
of contexts, including higher education and government contracting. ${ }^{120}$ Accordingly, if legal abolition is required before a societal practice can be deemed immoral, then opponents of affirmative action must await a substantial change in American public policy before challenging affirmative action as immoral and unconstitutional. In any event, as previously noted, conservatives have not waited for such developments, but instead argue that affirmative action is inherently immoral, and have made such arguments since the late 1960s and 1970s, when national support for affirmative action was at its height.

The claim that morality is no more than a question of popular consensus is not without adherents. However, for those who believe that morality is more enduring than current public opinion-as conservatives generally do-and that crimes against humanity transcend time and national borders, slavery and discrimination against black people did not become wrong only when American society came to recognize it as such. The American institutions of slavery, segregation, and discrimination were egregiously wrong and inhumane from their inception.

President George W. Bush, a prominent conservative and national Ieader, defends the fairness of judging slavery as unjust in hindsight. Despite America's acquiescence in the institution of slavery during its practice, Bush condemned slavery as violating the "natural rights of man," 121 and further observed:

At every turn, the struggle for equality was resisted by many of the powerful. And some have said we should not judge their failures by the standards of a later time. Yet, in every time, there were men and women who clearly saw this sin and called it by name. We can fairly judge the past by the standards of President John Adams, who called slavery "an evil of callosal [sic] magnitude." We can discern eternal standards in the deeds of William Wilberforce and John Quincy Adams, and Harriet Beecher Stowe, and Abraham Lincoln. ${ }^{122}$

120. See Katherine Hutt Scott, 4 States Weigh Return to Affirmative Action, USA TodaY, July 15 , 2003, at D8 (describing the effect of Grutter v. Bollinger on California, Washington, and Florida, all of which prohibit affirmative action by state law), available at 2003 WL 5315313; see also CAL. CoNST. art 1, $\S 31$ (added by lnitiative Measure (Prop. 209, approved Nov. 5, 1996)); WASH. Rev. CoDE. $\S$ 49.60.400 (1999); One Florida Initiative, Fla. Exec. Order No. 99-281 (Nov. 9, 1999), available at http://www.state.fl.us/eog/executive_orders/1999/november/eo99-281.html (last visited Dec. 28, 2003); Exec. Order 11,246, 30 Fed. Reg. 12,319 (Sept. 24, 1965), amended by 62 Fed. Reg. 44174 (Aug. 19, 1997) (codified at 41 C.F.R. pt. 60-1 to 60-60) (setting affirmative action requirements for federal government contractors).

121. Press Release, Office of the Press Secretary (White House), President Bush Speaks at Goree Island in Senegal (July 8, 2003), available at http:/www.whitehouse.gov/news/releases/2003/ 07/20030708-1.html (last visited Dec. 28, 2003).

122. Id. 
In Bush's view, "[t]he rights of African Americans were not the gift of those in authority." 23 Rather, "[t]hose rights were granted by the Author of Life, and regained by the persistence and courage of African Americans, themselves." 124 Those who failed to recognize the injustice of slavery had lost sight of divine truth: "Christian men and women became blind to the clearest commands of their faith and added hypocrisy to injustice. A republic founded on equality for all became a prison for millions." ${ }^{125}$ Thus, for President Bush at least, the wrongfulness of slavery transcends the moral choices of society at a particular point in history.

\section{The Collective Responsibility of Past Society}

Assuming past societal discrimination was immoral, there remains the difficulty of attributing responsibility for the sins of past generations to current socicty. The first objection to such an attribution is that America as a whole was not responsible for individual acts of past discrimination. The second, discussed in Part II.A.3, is that the responsibility of past society does not pass to the current generation.

For purposes of this argument, the term "societal discrimination" refers to the myriad individual instances of discriminatory decisions and actions by different individual actors. Of course, not all Americans participated directly in slavery or discrimination. By the early nineteenth century, northern states had abolished slavery, and only a minority of white southerners owned slaves at the time of emancipation. ${ }^{126}$ Abolitionist whites opposed slavery, and others had little or no direct involvement in the institution. Similarly, after emancipation, many Americans opposed or did not support segregation or other discrimination against blacks. Onc might argue that those who actually practiced slavery or discrimination bear responsibility for their individual conduct, but those members of society who did not engage in such discrimination do not share their remedial responsibility. If corrective justice imposes a moral obligation only upon those actors who perpetrated wrongful acts, then only those individuals who practiced slavery or discrimination are morally responsible for correcting any remaining effects of past discrimination.

Indeed, it may be questioned whether American "society" is a collective entity to which any obligation may be ascribed. To be sure, American law routinely imposes liability on collective entities, such as governments, corporations, churches, and other institutions, but such entities have a

123. Id.

124. Id.

125. Id.

126. See, e.g., Derrick Bell, Race, Racism \& American law 8-10 (2d ed. 1980); Leon F. Litwack, North of Slavery 3-20 (1961). 
cognizable structure and locus of decision making. ${ }^{127}$ American society, in contrast, refers to the mass of American people, a disconnected collection of different actors, including the federal government, numerous state and local governments, and private individuals and organizations. It is thus questionable whether society can meaningfully be described as a single actor responsible for past discrimination or its effects.

Focusing on the American people as a collective wrongdoer is admittedly less straightforward than focusing on the federal government, the actor to which many reparationists attribute primary responsibility for past discrimination. ${ }^{128}$ Notwithstanding that American society is a more amorphous concept than the federal government, it is a more accurate and appropriate locus of responsibility for past discrimination. This section first explains how American society as a nation is a collective entity capable of incurring obligations chargeable to the entire citizenry, and then considers the extent to which America is collectively implicated in past discrimination.

The idea of the American people as a nation, distinct and superior to the federal government, is a fundamental precept of our constitutional order. "We the People" established the United States through the ratification of the Constitution. ${ }^{129}$ In theory, the American people are the principal and the federal government is the primary agent through which the people govern. We the people elect the President and Congress as representatives, and when the federal government acts, it does so not exclusively on its own behalf, but on behalf of the national community. For example, in apologizing and making compensatory reparations to Japanese Americans for the relocation and internment many suffered at the hands of the federal government during World War II, Congress expressed that it was doing so "on behalf of the people of the United States." 130

As the congressional reparations example also demonstrates, the collective character of our nation extends to the fulfillment of obligations incurred on the nation's behalf. We exact taxes from the American people, for example, and compel American soldiers into mortal combat in fulfillment of collective obligations arising from commitments to ourselves and to other nations.

127. See, e.g., Meir Dan-Cohen, Between Selves and Collectivities: Toward a Jurisprudence of Identity, 61 U. CHI. L. REv. 1213, 1229-30 (1994) (discussing the manner in which law addresses collective entities).

128. See, e.g., Magee, supra note 6, at 894.

129. See U.S. CoNST. pmbl. ("We the People of the United States, in order to form a more perfect Union, . . . do ordain and establish this Constitution for the United States of America.").

130. See Civil Liberties Act of 1988, Pub. L. No. 100-383, 102 Stat. 903 (1988) (codified at 50 U.S.C. app. $\S 1989(2000)$ ) (stating that one purpose of the Aet is to "apologize on behalf of the people of the United States for the evacuation, relocation, and internment of such citizens and permanent resident aliens"). 
The American people not only act in a collective capacity, but also identify as such. We identify as Americans and take responsibility for events and endeavors of national significance, such as war and the space program. ${ }^{131}$ Indeed, as Meir Dan-Cohen argues, with respect to such events "so prominently linked to American identity... [d]enying responsibility for all such objects and events is tantamount to repudiating one's American identity altogether." 132 Our collective identity, moreover, is not limited to activities directly involving the federal government. We take pride as Americans, for example, in the success of American athletes in international competitions and in the outstanding contributions by Americans to knowledge and peace. Further, we are collectively moved to action on behalf of American lives endangered by disasters, natural and human-made. It is also worth noting that, in the name of patriotism, conservatives emphasize collective obligations derived from our national identity as Americans. Examples of controversies in which conservatives stress obligations of patriotism and national identity include flag burning, the pledge of allegiance, and most recently in rallying support for the President and our troops in the war against Iraq. In short, America as a people has a collective identity with respect to events that implicate the nation as a nation, a people not of different states and localities, but of a collective whole-America. ${ }^{133}$

It would seem to follow from the nature of America as a nation that its members may fairly be charged collectively for the cost of fulfilling national obligations, whether or not every member bearing the cost personally participated in the practices upon which the nation's obligation is based. The claim here is simply that membership in a collective entity brings with it certain benefits and costs, rights and obligations, as incidents of membership. A principal reason for forming and joining a collective group is to gain certain advantages not available to disassociated

131. Meir Dan-Cohen makes a similar point in discussing ways in which people collectively identify and take responsibility as groups:

[W] hether or not recognized by law, instances of collective responsibility abound. From the relatively simple case of the baseball player who reports in the first person plural about an inning or a victory ("we scored," "we won") in a game in which she did not even participate, to the more complicated situation of the American for whom space missions or the Vietnam War are matters of personal pride or shame, we witness all around us collective affiliation leading people to treat the actions of others as their own.

Meir Dan-Cohen, supra note 127, at 1237.

132. Meir Dan-Cohen, Responsibility and the Boundaries of the Self, 105 HARv. L. REV. 959, 987

(1992).

133. Commenting on the significance of American identity, Frances Lappé observes:

To be an American has always meant to take pride in more than the grandeur of our natural endowment, the strength of our armed forces, or the genius of our Nobel laureates. More than anything, we are proud that America stands for something, a set of enduring values that have given us a common identity in the midst of incredible diversity-values that have made us one people.

Frances MoOre LapPÉ, Rediscovering America's Values 3 (1989). 
individuals. The consideration for such advantages gained from group membership is that burdens incurred or experienced by the collective group may fairly be shared by the entire membership. A member cannot fairly claim the right to retain membership in the collective entity, including any benefits flowing therefrom, while denying any share in the burdens of membership.

To illustrate, consider government reparations to victimized groups, such as those paid by the United States to Japanese Americans and their descendants, ${ }^{134}$ or those paid by Germany, with the United States' encouragement, to Holocaust survivors and their descendants. ${ }^{135}$ The vast majority of American and German taxpayers bearing the cost were not personally responsible for the governmental crimes committed during World War II. ${ }^{136}$ Similarly, a corporation may be held liable for corporate acts predating the tenure of current officers, and the corporation's shareholders may have to bear the cost of corporate liability, even if they were not shareholders at the time of the acts giving rise to liability. Membership in a collective group, including the American people as a nation, involves burdens as well as benefits. It should therefore not stand as a bar to imposing the cost of societal obligations on the American people that not all its members participated in or endorsed practices for which society as a whole bears collective responsibility. ${ }^{137}$

Given that collective responsibility may sometimes attach to American society, the question is whether past societal discrimination, such as slavery and segregation, sufficiently implicated the nation as a whole to justify ascribing responsibility to American society for its effects. Certainly those actions taken directly by the federal government may fairly be ascribed to the nation. For example, the relocation of Japanese Americans was authorized by executive order and congressional

134. Cf. Chisolm, supra note 4, at $721 \mathrm{n} .264$ (observing that children of Japanese-American ancestry who were born after their families were relocated by the United States govermment during World War 11 have been entitled to compensatory reparations).

135. See generally Nana Sagi, German Reparations: A History of the negotiations (1980). The United States has intervened on behalf of Jewish Americans seeking reparations. See Princz v. Federal Republie of Germany, 26 F.3d 1166, 1168 (D.C. Cir. 1994) (noting intervention by the Clinton administration).

136. As Vincene Verdun observes, the following Americans bore the cost as taxpayers of the congressional reparations to Japanese Americans interned during World War 11 even though such people were not personally responsible for the internment: "l) people who were not born in 1941 ; 2) people who were alive but objected strenuously to the internment; 3) people who immigrated to the United States after the internment was over; and 4) a host of other people who just had nothing whatsoever to do with it." Verdun, supra note 4, at 653.

137. Cf. Thomas Nagel, Equality and Partiality 99-100 (1991) ("[In an egalitarian system,] it is essential that the society should be regarded by its members as responsible for how things are, if different feasible policies and institutions would result in their being different. And if the society is responsible, Imembers of societyl are responsible through it, for it is their agent."). 
legislation, and was carried out by the United States military. ${ }^{138}$ Such direct involvement by federal governmental actors created an obligation on the part of the American people, an obligation acknowledged and partially fulfilled by congressional reparations. ${ }^{139}$ In the case of slavery and discrimination against blacks, to the extent these practices were protected and supported by congressional enactments, federal executive actions, and judicial interpretations by federal courts, the American people as a whole share in the responsibility. ${ }^{140}$

But what of racial discrimination practiced by nonfederal actors? In contrast to the Japanese American relocation, racial discrimination against black Americans involved many more perpetrators than the federal government alone. All levels of government and many private actors in every state practiced discrimination to significant, though varying, degrees. Discrimination was so pervasive that several scholars have described America's subordination of blacks as a caste system. ${ }^{141}$ That Iocal government and private actors played a critical role in societal discrimination and its effects arguably undermines an obligation attributable to the nation as a whole.

Indeed, the federal government arguably lacked the eapacity to protect blacks from state and private discrimination. For much of America's history, the federal government probably lacked sufficient economic resources to abolish slavery and effectively enforce antidiscrimination laws. Moreover, it appears to have lacked the politieal support to protect blacks, at least outside the Civil War and Reconstruction period. The federal government also arguably lacked constitutional authority to address racial discrimination, both before and after the Civil War. Before the Civil War, the Constitution protected property rights in slaves. After the Civil War,

138. See Susan Kiyomi Serrano \& Dale Minami, Korematsu v. United States: $A$ "Constant Caution" in a Time of Crisis, 10 Aslan L.J. 37, 40 (2003); see also ERIC K. YAMAMOTO ET AL., RACE, Rights ANd REPARATION: LAW AND THE JAPANESE AMERICAN INTERNMENT 100-01 (2001).

139. See supra note 130 and accompanying text.

140. Explaining the responsibility of the citizenry for the policies of its government, Erich Loewy observes:

Governments ean only pursue policies and carry out programs with the tacit approval of the citizenry. While this holds particularly true in truly democratic societies, it is to a lesser extent (and especially in the long run) true even of dietatorships. No power structure can, over the long haul, pursue policies diametrically opposed to the general will without collapsing. The citizenry, while it need not actively embrace the government's policies, must either not oppose or not really care about them. Among others, it is this truth that underwrites historical guilt, be it in Germany, the United States, the Far East, or anywhere.

Erich H. Loewy, Making Good Again: Historical and Ethical Questions, in Christian Pross, Paying for the Past: The Struggle over Reparations for Surviving Victims of Nazi Terror 185 , 194 (Belinda Cooper trans., Johns Hopkins Univ. Press 1998) (1988).

141. See, e.g., Kenneth L. Karst, Belonging to america: Equal Citizenship and the Constitution (1989); MYRDAL, supra note 57; RoBinson, supra note 6, at 202 (diseussing Myrdal's theory); J.M. Balkin, The Constitution of Status, 106 YALE L.J. 2313 (1997); Fiss, supra note 111; Jed Rubenfeld, Affirmative Action, 107 YALE L.J. 427, 460-61 (1997); Cass R. Sunstein, The Anticaste Principle, 92 Mich. L. Rev. 2410 (1994). 
constitutional federalism constrained the extent to which the federal government could regulate areas of traditional state authority, particularly discrimination by private actors. ${ }^{142}$

Certainly, discrimination by state and private actors was an essential feature of societal discrimination, but the nation as a whole was nonetheless implicated in that discrimination. The legality of slavery and discrimination was a product of constitutional law, its content, enforcement, and interpretation. For example, rather than prohibiting slavery, the Framers intentionally drafted the Constitution to recognize and protect it. Rather than prohibiting private discrimination, or authorizing Congress to do so, the Fourteenth Amendment was intentionally limited to state action. The Constitution is the creation and responsibility of the American people. To the extent the Constitution disables the political branches of government from protecting blacks from discrimination, a fact that may mitigate the individual responsibility of a particular administration, it cannot relieve the nation of collective responsibility. As the fundamental charter of governmental powers and individual rights, the Constitution implicates the people as much as, and arguably more than, individual actions of governmental institutions.

It is not an answer that the Constitution was misinterpreted by the courts to protect slavery, private discrimination, or state-sponsored segregation, or underenforced by the political branches of the federal government. As previously noted, these governmental institutions act on behalf of the nation. Nor is it an answer that the federal government, including the courts, could not protect blacks, given economic and political realities. To the extent the American people refused to fund adequately or to politically support national measures to protect blacks from known and widespread discrimination, the political and economic weakness of the federal government is attributable directly to the American people themselves. Thus, the American people as a nation were implicated by those actions of federal institutions that directly supported discrimination. Further, the nation was implicated in the wholesale, nationwide, intergenerational nature of societal discrimination that found legal protection in the national Constitution. America's history of racial discrimination is, and always has been, "An American Dilemma." 143

142. See Civil Rights Cases, 109 U.S. 3 (1883) (holding that the Fourteenth Amendment prohibits only state-sponsored discrimination and does not authorize Congress to prohibit private discrimination).

143. The phrase, "An American Dilemma," comes from the title of the extensively researched work of Gunnar Myrdal. See MYRDAL, supra note 57. A penusal of respected historical works on racial discrimination in America suggests the extent to which discrimination was an institution of national significance, not merely that of isolated states or locales. See, e.g., MAURICE R. DAVIE, NEgroes IN american Society (1949); John Hope Franklin, From Slavery to Freedom: A History of Negro Americans (1947); E. Franklin Frazier, The Negro in the United States (rev. ed. 1957); George W. Williams, History of the Negro Race in America (photo. reprint 1968) (1883); Carter G. Woodson, The Negro in OUr History (1922). 
The boundaries of national legal responsibility under international law may provide further insight into the question of national moral responsibility. The United States has constitutionally recognized international law since the nation's origin. ${ }^{144}$ Under international law, a nation may bear responsibility for the actions of regional governments and private actors that result in widespread violations of individual rights (including slavery, torture, and genocide) if the nation fails to protect people adequately from such abuses. ${ }^{145}$ Indeed, violations of international law by any governmental actors, no matter how local, may be attributable to the nation even if the national government were unaware of or could not have prevented the abuse and even if the governmental misconduct violated national law. ${ }^{146}$ It is no defense under international law, moreover, that the constitutional law of a nation prevents the national government from protecting individual rights. ${ }^{147}$ Any constraints placed upon a government by the nation's constitution are thus understood by international law as the responsibility of the nation.

Not only does the United States recognize and accept international law generally, it has invoked the specific principles described above in attributing responsibility to other nations, and has acquiesced in their application to the United States. ${ }^{148}$ One example was the American hostage crisis of 1979-80, during which staff members of the American embassy in Iran were held hostage by a group of private militants. The United States

144. See U.S. CoNST. art. $1, \S 8$, cl. 10 (providing that Congress shall have authority to punish offenses against "the Law of Nations"); U.S. CONST. art. VI, cl. 2 (providing that treaties made under the authority of the United States "shall be the supreme Law of the Land"). The "law of nations" is often used interchangeably with "international law." See Beth Stephens, Federalism and Foreign Affairs: Congress's Power to "Define and Punish. . Offenses Against the Law of Nations," 42 WM. \& MARY L. Rev. 447, 449 n.l (2000) (citing Mark W. JanIS, AN INTROduction to International LAw 1 (1988)); see also Restatement of Foreign Relations, supra note 105, pt. I, ch. 2 introductory note, at 41 (1987) ("[T]he law of nations, later referred to as international law ...."). The phrase "law of nations" is sometimes used to refer to customary international law as distinct from legal obligations that derive exclusively from treaties.

145. See Restatement of Foreign Relations, supra note 105, $\$ 207 \mathrm{cmt}$. c. The United States is a party to the Convention Against Slavery and has often indicated agreement with the Universal Declaration of Human Rights, which prohibits slavery, torture, genocide, and inhumane treatment. See International Convention on Slavery, Sept. 25, 1926, 60 L.T.S. 253, available at http://www.unhchr.ch/html/menu3/b/f2sc.htm; see also Supplementary Convention on the Abolition of Slavery, the Slave Trade, and Institutions and Practices Similar to Slavery, Sept. 7, 1956, 266 U.N.T.S. 3, available at $\mathrm{http}: / / \mathrm{www}$.unhchr.ch/html $/ \mathrm{menu} 3 / \mathrm{b} / 30 \mathrm{htm}$.

146. See id. $\$ 207 \mathrm{cmts}$. b \& d.

147. See id. $\S 207 \mathrm{cmt}$. a (explaining that a state-in the sense of a nation, not a regional or provincial government within a federated system-is responsible for carrying out its obligations under international law regardless of whether the Constitution places federalism or other limitations on the authority of the state to meet its obligations); id. $\$ 115 \mathrm{cmt}$. b (explaining that a state cannot justify violating an international obligation on the ground that such obligation violates domestic constitutional or other law).

148. See id. $\S 207$, reporters' note 3 (stating that the United States consistently has accepted responsibility for acts of constituent states and has demanded the same from the national governments of other federal systems). 
successfully argued in the International Court of Justice that the acts of the militants were attributable to Iran because Iran's inaction throughout the crisis amounted to a "seal of approval."149 Moreover, when a mob of private individuals lynched a group of Italian nationals in New Orleans, Louisiana, the United States accepted responsibility for the failure of local authorities to protect the Italians. As a result, the United States voluntarily paid compensation to the government of Italy. More recently, since September I1, 2001, the United States has taken the position on the international stage that nations who tolerate terrorist organizations within their borders are implicated in the wrongdoing of such organizations, and America is prepared to wage war against any such nations who "harbor" terrorists. ${ }^{150}$

The foregoing principles of international law suggest that the failure of the United States to protect black people from slavery and discrimination practiced by state and local governments and private individuals represents a series of commissions and omissions for which the United States is responsible as a nation. America not only knowingly "harbored" slaveowners, segregationists, and other discriminators, it afforded them constitutional and other legal protection. Consistency would seem to require ascribing responsibility to America for the widespread and ongoing discrimination against blacks that defined so much of American history.

The relevance of international law, however, should not be overstated. Principles for resolving questions of national legal responsibility do not necessarily determine questions of national moral responsibility. Yet, to the extent such principles derive from moral judgments about the relationship between nations and persons, ${ }^{151}$ or reflect generally accepted reasons for attributing to a nation the acts of regional governments or private individuals, they support the plausibility of the claim that America as a nation is implicated in the societal discrimination endured by blacks in the United States.

149. See id. $\$ 207$, reporters' notes 4-5; Case Concerning United States Diplomatic and Consular Staff in Tehran (U.S. v. Iran), 1980 I.C.J. 3, 29 (May 24).

I50. See Dan Balz, A Resolute and Focused Call to Arms, WASH. Post, Friday, Sept. 2I, 200I, at AI (quoting President Bush's speech to a joint session of Congress in which Bush warned that "[f]rom this day forward, any nation that continues to harbor or support terrorism will be regarded by the United States as a hostile regime.").

151. Principles of international law relating to individual rights derive in part from principles of natural law. See ReSTATEMENT of FoREIGN RELATIONS, supra note 105, pt. VII introductory note, at 146 (stating that international law regarding the rights of foreign nationals, and more recently human rights in general, are "derived from historic conceptions of natural law, as reflected in the conscience of contemporary mankind and the major cultures and legal systems of the world"). Jack Goldsmith and Eric Posner have questioned this view, arguing that international law reflects exclusively the economic self-interest of nations. See Jack L. Goldsmith \& Eric A. Posner, A Theory of Customary International Law, 66 U. CHI. L. REv. 1113 (1999). Whatever the merits of their critique, the overwhelming acceptance of the international law principles outlined above by countries large and small, weak and powerful, suggests that at a minimum such principles are consistent with common notions of faimess. 


\section{The Collective Responsibility of Current Society}

Assuming past society bore some responsibility for past discrimination, the question remains whether current society bears that responsibility. Skeptics could argue that the society responsible for past discrimination no longer exists. No one alive today owned slaves. And only a small percentage of Americans alive today participated as adults in discrimination during the period in which it received official and widespread support. Thus, it may be unfair to require current members of society to bear responsibility for the wrongs of previous generations. ${ }^{152}$ The risk of unfairness is arguably greater when particular individuals must bear the cost of the entire society's responsibility, as in cases where affirmative action results in denied opportunities to those individuals.

Whether America today is responsible for national obligations incurred in the past raises the question of identity through time, that is, whether America is a continuing entity, such that practices attributable to the nation at one point in time are fairly attributable to the nation at a subsequent point in time. As a general rule, provided there has been no official dissolution or reconstitution, a nation continues over time despite turnover in membership. ${ }^{153}$ As Jeremy Waldron observes, "a tribe, a nation, or a community... [is an] entity that endures over time in spite of mortality of its individual members." 154 America is not a series of different nations from minute to minute, or day to day, as individuals join or depart the citizenry by birth, death, or immigration. Indeed, the very idea that our Constitution binds generations born centuries after its ratification is premised upon the continuity of the nation. Conservatives in particular emphasize the principle that present and future generations of Americans are bound by the original intentions of the Framers. ${ }^{155}$ Indeed, conservative-Ied

152. See HACKER, supra note 29 , at 4 (observing that most whites deny responsibility for the condition of blacks because they neither owned slaves nor personally participated in discrimination).

153. An analogy to corporate identity may also be helpful. A corporation retains the same identity from one day to the next, notwithstanding changeover in shareholders or employees. See PETER A. French, Collective and Corporate Responsibility 27 (1984). Indeed, corporate law recognizes that a complete change in name and ownership need not preclude a corporation from having a continuing identity if it represents a "continuing enterprise." See Phillip I. Blumberg, The Continuity of the Enterprise Doctrine: Corporate Successorship in United States Law, IO FLA. J. INT'L L. 365 (1996).

154. Jeremy Waldron, Superseding Historic Injustice, 103 EThICs 4, I5 (1992).

155. For example, the prominent conservative jurist Robert Bork argues that the Constitution should be interpreted aceording to the original understanding of its terms. ROBERT H. BORK, TEMPTING of America: The Political Seduction of the Law 75, 76-77, 143-45, 154-55 (1990) (arguing that the only proper way to have interpreted the Fourteenth Amendment in Brown v. Board of Education is according to the original understanding of that amendment).

Reflecting on the extent to which American society identifies with and benefits from prior generations, Ali Mazrui poses the question, "[i]f Americans of the 20th and 21 st century are prepared to inherit the intellectual and moral assets of the Founding Fathers, should they not also accept the moral debts of the Founding Fathers?" Ali A. Mazrui, Who Should Pay for Slavery?, WorLd Press REv., 
legal challenges to affirmative action policies rely on the continuing force of the Fourteenth Amendment's commitment to equal protection, a commitment made by the nation over 130 years ago, before any living affirmative action opponent was born.

Given a sufficient period of time, the composition of society changes completely. However, at each point in between, the collective identity of America persists. Nor has there been any event since the Founding that officially dissolved and reconstituted the American nation. The most plausible candidate for such an event, the Civil War, officially preserved America as one nation, producing only amendments to the continuing constitutional charter. ${ }^{156}$

Just as America today is, through a chain of moments, the same America as it was one or one hundred years ago, America today is responsible for its discriminatory practices of the past decades and centuries. As an obligation held today by the nation as a collective whole, the cost of fulfilling it can fairly be charged to current members of American society. That most Americans today were not personally involved in the slavery or discrimination on which the inherited obligation is based is beside the point. Indeed, the nation's present obligation is not properly characterized as "inherited," as the nation that originally incurred the obligation has never ceased to exist. As Vincene Verdun observes, "[s]ociety, unlike individuals, does not have a natural life. The society that committed the wrong is still thriving." 157

The frequent and persistent complaint that current members of society were not personally involved in past discrimination seems to reflect the fallacious view that societal responsibility necessarily implies personal guilt. ${ }^{158}$ The inhumanity of discrimination understandably leads some people, both black and white, to infer from a charge of societal participation that all members of society are or were personally blameworthy for the discrimination. Some blacks who believe in society's responsibility for America's racial history blame all whites as personally responsible for that history. And many of those who recognize the lack of personal

Aug. 1993, at 22, quoted in Elazar Barkan, The Guilt of Nations: Restitution and Negotiating Historical INJUSTICES 302 (2000).

156. Notably, the Fourteenth Amendment expressly holds the United States responsible for any public debts or other obligations incurred by the United States in suppressing the Confederacy. U.S. CoNST. amend. XIV, $\S 4$ ("The validity of the public debt of the United States, authorized by law, including debts incurred for payment of pensions and bounties for services in suppressing insurrection or rebellion, shall not be questioned."); see generally Susan Poser \& Elizabcth R. Varon, United States v. Steinmetz: The Legal Legacy of the Civil War, Revisited, 46 AlA. L. REv. 725, 758-61 (1995).

I57. Verdun, supra note 4, at 638.

158. See, e.g., Michael K. Ross, Book Notice, Affirmative Action at Work: Law, Politics, and Ethics by Bron Raymond Taylor, 90 Mich. L. REV. 1356, 1359 (1992) ("People strongly opposed to affirmative action commonly objected that affirmative action is essentially reverse discrimination against whites, that people should be hired solely on the basis of merit, and that past discrimination does not justify sacrifices by white males who are not personally responsible for past injustices."). 
responsibility of most whites alive today conclude that current society also cannot be collectively responsible. They are both wrong. If society as a collective entity is morally responsible, then its members may be called upon, as an incident of membership-not personal blamc-to share the cost incurred by society in meeting its moral obligations. ${ }^{159}$

Accordingly, to the extent America as a nation is responsible for redressing the effects of past discrimination, thc cost of redress is fairly borne by all current members of society. These members include activists in the civil rights movement, descendants of abolitionists, recent immigrants, and even blacks whose lives have been negatively impacted by America's discriminatory past. These blacks are simultaneously entitled to remedial aid from American society because of their status as victims, and obligated to share in the cost of such aid because of their status as citizens. Such a circular consequence also followed from the congressional reparations paid to Japanese Americans, whose taxes contributed to their own compensation.

Finally, a few points ameliorate the concern that particular individuals should not be disproportionately burdened by programs designcd to remedy society's collective responsibility. First, such a concern does not negate societal responsibility, but rather counsels restraint in designing remcdies to fulfill that responsibility. We indeed should consider who is most acutely burdened by remedial programs, but that should not preclude such programs if the cost to individuals can be adequately minimized or spread among many people. Second, any governmental policy enacted for the collective interest will impose disproportionate burdens on some individuals. A government-sponsored airport or highway, for example, may burden local residents more than others. Similarly, government expenditures to meet particular financial obligations may decrease the funds available for other purposes that would have benefited specific people. For example, to service the national debt, meet military commitments, or provide earthquake relief, Congress may have to spend less on college scholarships. As a result, some individuals may not receive scholarships because congressional funds were directed elsewhere. The potential losers of any public policy should be considered, but the possibility that some people may be burdened should not necessarily bar its implementation.

159. See BARKAN, supra note 155, at 293 (explaining that restitution for American slavery is a question of national, not personal, responsibility); Loewy, supra note 140 , at 194 (observing that an obligation need not stem from personal culpability, but from communal responsibility).

Mahatma Ghandi recognized the distinction between group responsibility and the personal responsibility of group members, criticizing in the strongest terms the unjust character of colonial Britain while maintaining that individual British citizens were not necessarily to blame. See REINHOLD Niebuhr, Moral. Man and Immoral Society: A Study in Ethics and Politics 249 (photo. reprint 200I) (1932) ("It is possible, therefore, for me to condemn the system [of British imperialism] in the strongest terms, without considering you [an Englishman] to be bad and without imputing bad motives to every Englishman." (quoting Mahamta Ghandi)). 
Moreover, similar individualized burdens are characteristic of conservative-led efforts to make whole the victims of affirmative action. Consider the example of a white applicant denied admission to a public university on grounds of race. The applicant might sue the university for compensatory damages and a court injunction requiring his admission. Any damages awarded in such a lawsuit would be charged to state taxpayers who likely had nothing to do with the discrimination. In addition, an injunction would harm a specific innocent individual because given the delay inherent in litigation, an injunction would likely require admission of the applicant to a class of entering students subsequent to the one from which he initially was excluded because of his race. The applicant's court-ordered admission would thus result in the exclusion of another applicant who bore no personal responsibility for the applicant's previous exclusion, and who was not the student who took the applicant's place in the previous class..$^{160}$

In sum, the case for holding American society responsible for past discrimination depends on the plausibility of recognizing American society as a collective and continuing nation, the obligations of which fairly pass through time and generations. It may also require accepting the injustice of past discrimination independently of whether society believed it morally permissible during its official practice. The claim that present society is responsible for past societal discrimination thus faces difficulties that may be dispositive to some skeptics. However, to the extent the American nation ever acts as a collective people whose obligations extend over time, the societal protection of slavery and discrimination, a widely known institution of national and intergenerational scale, plausibly qualifies as a practice for which the entire nation bears collective responsibility. Whether slavery and official discrimination were immoral when practiced, few, if any, more unjust regimes existed in human history. Those who would leave such judgments to the consensus of the time, however, may hold America harmless, as there can be no obligation in corrective justice without an injustice to correct.

160. Paul Brest notes the cost to innocent individuals in the employment context that results from remedying racial discrimination:

Even the most conventional and undisputed specific remedy-an order requiring the employer to accord an identifiable discriminatee priority for the next vacancy-adversely affects another applicant for the vacancy who would otherwise have gotten the job. The law's traditional indifference to the competitor's equities is partly explained by the view that he has no "right" to the job and that no reasonable expectations will be frustrated by denying it to him. Additionally, the prior act of discrimination is treated as giving the discriminatee a special claim against the employer-like a priority in bankruptcy-to which all others are subordinated.

Paul Brest, The Supreme Court, 1975 Term-Foreword: In Defense of the Antidiscrimination Principle, 90 HARv. L. Rev. 1, 37 (1976). 


\section{B. Proximate Causation: "Breaking" the Chain of Societal Responsibility?}

Assuming the initial elements of the corrective justice case are satisfied-that present society is fairly charged with having wrongfully engaged in past societal discrimination-the next question is whether that discrimination is a morally cognizable cause of the harm that persists today. This Article assumes that actual causation exists, although Part III.A will consider difficulties in precisely measuring and identifying discrimination's consequenccs. This section questions causation on normative grounds, that is, whether society should be treated as a cause of black disadvantage today in light of the intervention of adverse choices by some black people and the passage of time. Such is the concept of proximate cause, a concept familiar to American law that limits which actions or events that in fact caused certain subsequent effects should be understood as responsible for such effects.

Because the goal of assigning responsibility is achieving justice, the question is whether it is morally just or fair to society to persist in holding it responsible for past discrimination. Two reasons support limiting society's moral responsibility for past discrimination without denying society's causal influence on present conditions. First, many of the problems experienced by blacks today are arguably of their own making, through behaviors such as neglecting parental responsibilities or eschewing acadcmic achievement in favor of unproductive or criminal behavior. If black people are to be respected as competent decision makers, then they, not society, must be held responsible for their choices. Second, too much time has arguably elapsed since America officially sanctioned racial discrimination to hold society responsible for discrimination's attenuated effects. In other words, the past is past, and it is time to move on.

These objections are consistent with corrective justice theory. No account of corrective justice would hold that causation-in-fact is irrebuttably sufficient to establish moral responsibility. It would be unfair to hold a causal agent responsible for all the effects of his wrongful conduct no matter how unlikely or far into the future such effects extend. Actual causation is but a starting point for establishing responsibility, making the causal agent "eligible"161 for responsibility.

\section{The Significance of Intervening Choice}

This section considers the argument that society cannot be held responsible for the problems facing black people to the extent that such

161. Writing about claims in tort for compensation arising from negligent conduct, Kenneth Abraham describes the plaintiff's establishment of actual causation as making a defendant "eligible" for liability, depending on whether the defendant is also determined to be a proximate cause of the plaintiff's injury. See Kenneth S. Abraham, The Forms and Functions of Tort Law 100 (1997). 
problems result from the voluntary choices of individual blacks. The high rates of nonmarital births and family breakdown in many poor black communities, for example, involve choices to engage in unprotected sexual intercourse and to abandon family responsibilities. High crime rates can be explained in part by decisions to join gangs, to sell drugs, and to kill. Low voter turnout in black communities reflects in part decisions not to participate in the political process. Disparities in educational achievement between blacks and whites are due in part to black parents' lack of support for or interest in their children's education. Indeed, some social scientists have identified the emergence of an "oppositional culture" in many poor, urban, predominantly black communities. This culture tends to devalue academic achievement, work, marriage, and civic responsibility, while encouraging government dependence, promiscuity, substance abuse, and crime. ${ }^{162}$ The choices fostered by such a culture are destructive to these communities. Moreover, as years pass and new generations are raised, an even greater number of choices intervenes between past societal discrimination and the present.

In focusing on irresponsible and blameworthy conduct by blacks, this Article does not mean to suggest that most blacks engage in such misbehavior, or that other factors do not also contribute to black disadvantage. However, recognizing that individual choices may exacerbate the problems facing black communities raises important questions about societal responsibility for the plight of such communities. If societal responsibility is ever to end, intervening choice may provide the most persuasive reason. Conversely, if such choices should not absolve society of responsibility, even where personal choices are significant, then the case for societal responsibility should be on even firmer ground with respect to other conditions plausibly linked to America's racial history in which black people's responsibility is less implicated. Some examples include the poor quality of predominantly black urban public schooIs, ${ }^{163}$ the lack of intergenerational

162. See MASSEY \& Denton, supra note 46, at 8-9, 130-47, 165-70 (arguing that residential segregation created conditions for the emergence of an oppositional culture that devalues work, education, and marriage, and fosters destructive behavior such as crime, teenage pregnancy, and drug abuse); see also Kenneth B. Clark, Dark Ghetto: Dilemmas of Social Power 22-27 (1965) (arguing that residential segregation produced "dark ghettos" characterized by "low aspiration, poor education, family instability, illegitimacy, unemployment, crime, drug addiction and alcoholism, frequent illness and early death").

163. Gary Orfield et al., Losing Our Future: How Minority Youth Are Being Left Behind By the Graduation Rate Crisis, The Civil Rights Project at Harvard University 10 (2004); see also JonathaN Kozol, Savage Inequalities: Children in America's Schools (1992) (describing statistical and experiential evidence of educational disparities between wealthy and impoverished school districts; noting the concentration of nonwhite students in poorer districts). 
wealth in black families, ${ }^{164}$ and the persistence of intentional discrimination. ${ }^{165}$

Some commentators, particularly from the right, emphasize the importance of individual responsibility for immoral choices. They argue that those black people who engage in blameworthy conduct should be held personally responsible for the effects of their choices. Whatever the effects of past societal discrimination on the conditions in which black people live today, such conditions do not coerce blacks into committing crime or render them incapable of moral reasoning. To attribute responsibility to society for the problems of blacks would inappropriately suggest that blacks should be excused for their behavior. Such a conclusion patronizes blacks and is unfair to the individuals and communities of all races who are victimized by crime. Thus, the implication of intervening choices by blacks is that society should be absolved of whatever responsibility it ever had for the lingering effects of slavery and discrimination.

Some observers from the left, in contrast, appear to deny that black people have any personal responsibility for their condition or conduct. Believing that destructive behavior by blacks is caused by societal discrimination, they conclude that blacks should be excused for such behavior. Some have advocated, for example, a "black rage" or "rotten social background" defense that would excuse some black defendants from criminal liability because of their experience with racism or with conditions created at least in part by societal discrimination. ${ }^{166}$ Some scholars go

164. See Oliver \& Shapiro, supra note 4, at 2 (discussing the significance of wealth, which is more broadly understood than income, in determining life opportunities, and the extent to which a person's wealth derives from the wealth of previous generations within the family).

165. See sources cited supra note 46 (discussing the persistence of racial discrimination).

166. For discussions of the "rotten social background" and "black rage" defenses, see HARRIs, supra note 5, at 147-62 (defining the black rage defense as a diminished capacity excuse to crime); Patricia J. Falk, Novel Theories of Criminal Defense Based Upon the Toxicity of the Social Environment: Urban Psychosis, Television Intoxication, and Black Rage, 74 N.C. L. REv. 731 (1996) (arguing that socially toxic factors, such as racism, poverty, and crime, can accumulate upon particular individuals so as to cause criminal and other dysfunctional behavior). For an exploration of how racism may support a provocation defense under Canadian law, see Camille A. Nelson, (En)raged or (En)gaged: The Implications of Racial Context to the Canadian Provocation Defence, 35 U. RICH. L. REv. 1007 (2002).

One of the first criminal cases involving a "rotten social background" defense was United States $v$. Alexander, 471 F.2d 923 (D.C. Cir. 1973). The black defendant killed a white Marine after an altercation involving racial epithets directed at the defendant. The defendant claimed he acted from an irresistible impulse caused by the racism and economic deprivation he experienced as a child that caused him to hate white people. The trial court denied the defense on the ground that, regardless of whether the defendant's background contributed to his actions, it had not rendered him mentally incompetent. Id. at 926, 928-29, 949-51. The appellate court affirmed over the dissent of Judge Bazelon, who argued that a rotten social background had deprived the defendant of control over his actions even if he remained sane at the time of the crime. Id. at 957-65 (Bazelon, C.J., dissenting). Judge Bazelon subsequently initiated scholarly debate over the defense. See David L. Bazelon, The Morality of the Criminal Law, 49 S. CAL. L. REv. 385, 403 (1976) (defending the rotten social 
so far as to excuse morally all blacks who commit crime on the ground that societal discrimination caused all such behavior. ${ }^{167}$ To attribute responsibility to blacks for conduct caused by societal discrimination would be, in their view, to blame the victim.

Several fallacies appear to underlie the foregoing debate. First, some proponents of societal responsibility apparently assume that causation necessarily implies responsibility on the causal agent's part. Believing that society, through discrimination, caused present conditions, they conclude that society is necessarily responsible for such conditions. However, causation does not necessarily imply responsibility. The claim that past societal discrimination caused certain conditions may be plausible as an explanation, a description of actual causation, but may not be justified as an ascription of responsibility to society for such conditions. As the concept of proximate cause recognizes, causation-in-fact does not necessarily establish responsibility, particularly for subsequent events that result more immediately from intervening voluntary choices.

Another implausible assumption reflected in arguments from the left is that causation necessarily excuses the conduct of those affected. Believing that self-destructive behavior by black people is caused by societal discrimination, these advocates conclude that black people are not responsible for that behavior. Such reasoning confuses causation with coercion. One whose conduct is coerced, that is, a product of conditions that deprive him of the capacity to make a voluntary choice, may lack responsibility for his conduct. Absent coercion, however, one who chooses to engage in wrongful conduct is not immune from personal responsibility simply because the choice to commit the misconduct was influenced by prior events, even if those events made the choice difficult. ${ }^{168}$ Taken to the extreme, this position is inconsistent with the very idea of personal responsibility, as no choices are free from the influence of prior events. Accordingly, it does not follow from the observation that societal discrimination has caused a disproportionately high rate of harmful or

background defense); Stephen J. Morse, The Twilight of Welfare Criminology: A Reply to Judge Bazelon, 49 S. CAL. L. REv. 1247 (1976) (arguing against the defense).

167. See Butler, supra note 5, at 715-16 (arguing that blacks who commit crime are not morally blameworthy in retributive terms, but conceding that some violent blacks should still be incarcerated to protect the black community).

168. Professor Stephen Morse makes a similar point in rejecting the claim that economic deprivation or a "rotten social background" should excuse criminal behavior simply because such behavior may be caused by such conditions. See Stephen J. Morse, Deprivation and Desert, in From Social Justice to Criminal Justice: Poverty and the Administration of Criminal Law 114, 140 (William C. Heffernan \& John Kleinig eds., 2000) ("l begin with the persistent but implausible claim that deprivation excuses because it causes criminal behavior."); accord Stephen J. Morse, Psychology, Determinism, and Legal Responsibility, 33 Neв. SYMP. ON Motivation 35, 50-54 (1986) (arguing that it is patronizing to make causation an excusing condition). 
self-defeating conduct by black people that blacks who engage in such conduct ought not be held personally responsible for the consequences.

To excuse completely blacks who engage in conduct destructive to themselves or to others simply because they must cope with difficult circumstances would also seem to endorse the assumption that they lack the character or self-control to act morally or in their best interests. Notice that the economic disadvantages disproportionately experienced by blacks, even if resulting in part from societal discrimination, are not necessarily different from conditions experienced by many white people. Despite this fact, we generally hold white people responsible for their choices, absent truly coercive conditions. Most black people, moreover, are law-abiding, moral, and productive citizens who raise their children accordingly, despite suffering the effects of discrimination. To excuse those blacks who fail to develop themselves or to contribute to society would seem to undermine the credit owed to those who succeed. Those who advocate such excuses not only treat blacks patronizingly, but also risk endorsing the prejudice that blacks should be feared as irresponsible or criminal.

Respecting black people as responsible persons does not, however, require the rejection of societal responsibility. Another fallacy, reflected on both sides of the debate, is that there can be only one actor morally responsible for a given harm. Those who believe that blacks are personally responsible for engaging in harmful conduct conclude that societal responsibility is therefore precluded. This "either-or" or sole-responsiblecause paradigm also seems to explain the position of many advocates of societal responsibility, who instead begin from the premise that society is responsible and conclude that therefore blacks are not. Admittedly, one can find some support for the sole responsible cause paradigm in the causation literature. Some scholars have argued that there can be only one cause of an event, ${ }^{169}$ and legal writing often seems to assume this to be true. ${ }^{170}$ Moreover, the doctrinal principle that intervening voluntary conduct may negate the responsibility of a prior wrongdoer ${ }^{171}$ suggests that responsibility may shift, in its entirety, from one party to another.

Notwithstanding this support, the notion of sole responsible cause is not well founded. However common it is for courts to speak of "the" cause when identifying responsible causal agents, there are numerous situations in which multiple causal agents are held responsible as proximate causes. ${ }^{172}$

169. See, e.g., Peter Unger, The Uniqueness in Causation, 14 AM. PHIL. Q. 177 (1977).

170. See Judith Jarvis Thomson, Causality and Rights: Some Preliminaries, 63 CHI.-KENT L. REv. 471,477 (1987) (observing that the locution "the cause," suggesting uniqueness, is common in legal writing).

171. See H. L. A. Hart \& Tony honoré, Causation in the law 136-62 (2d ed. 1985).

172. See Restatement (ThiRd) of Torts, $\S 29 \mathrm{cmt}$. b (Tentative Draft No. 3, 2003) ("Employing the term 'proximate cause' implies that there is but one cause-the cause nearest in time or geography 
For example, if $A$ assaults and injures $V$, and $V$ is subsequently given negligent medical treatment by $B$, both $A$ and $B$ can be held civilly and criminally liable for the resulting harm. Or, if a landlord negligently fails to secure an apartment building adequately, he may be responsible for injuries caused by an intruder against a tenant. And if $\mathrm{D}$ incites a riot, he may bc held responsible without precluding punishment of individual rioters. Holding an original wrongdoer responsible does not necessarily imply that a subsequent intervening actor is not also responsible for his contribution to the ultimate harm. ${ }^{173}$

Accordingly, with respect to harms resulting from the choices of black people, proximate cause analysis permits holding either society or black people responsible, or both. Consider also that responsibility might be shared or allocated on the basis of comparative fault. For example, society may be responsible for contributing, through historical discrimination, to the crimogenic conditions in certain urban ghettos while, at the same time, those who commit crimes as a result are held criminally responsible for their conduct. Accordingly, in considering the implications of intervening black choices for societal responsibility, we should not resist finding society responsible, or blacks for that matter, simply because we are committed to holding the other responsible as well. ${ }^{174}$

to the plaintiff's harm-and that factual causation bears on the issue of scope of liability. ... [However, m]ultiple factual causes always exist, . . and multiple proximate causes are often present.").

173. Proximate cause analysis also undermines the claim by some conservatives that although society may be obligated to the direct victims of slavery and discrimination, such obligation cannot, in principle, extend indirectly to their descendants. As proximate cause analysis reveals, however, American society commonly ascribes responsibility to a wrongdoer for harm he did not directly cause. One who foreseeably causes a third party to harm a victim may be judged a proximate cause of the victim's harm. See infra text accompanying notes 175-77. Not surprisingly, given that responsibility may extend through an intervening actor who also bears responsibility for harming the victim, responsibility can likewise extend through an actor who is himself a victim of the original wrongdoer. For example, one who directly harms another may be indirectly liable to the victim's spouse or child for lost companionship and support. And one who wrongfully converts property from someone who subsequently dies may be liable to the victim's heirs. Indeed, claims by Native Americans have been upheld for land taken from their ancestors almost two centuries earlier. See County of Oneida v. Oneida Indian Nation, 470 U.S. 226, 230, 240-44 (1985) (recognizing as timely a tribe's claim for infringement of property rights occurring 175 years ago); see generally Katharine F. Nelson, Resolving Native American Land Claims and the Eleventh Amendment: Changing the Balance of Power, 39 VILL. L. Rev. 525, 530-46 (1994) (discussing the historical background of Indian land claims). Proximate cause analysis recognizes that extending responsibility to all indirect victims may be unwarranted. Nevertheless, these examples demonstrate that responsibility toward indirect victims is not inherently impossible. America's responsibility toward black people should thus not be precluded simply because many disadvantages experienced by black people today result indirectly from discrimination against their ancestors.

174. I recognize that I have not provided a basis for determining the precise allocation of responsibility between society and black people for harmful conditions jointly caused. While that is an important question in determining the extent of society's obligation to remedy such conditions, my purpose in this Article is to establish the plausibility of society having any responsibility, and my point in the present discussion is that accepting some responsibility on society's part does not negate the possibility of holding personally responsible those black people who engage in blameworthy conduct. 
Nonetheless, even if the contribution of black people's choices toward their own plight does not necessarily relieve society of responsibility, such choices are surely relevant in assessing society's responsibility. It is arguably unfair to society to hold it responsible for all subsequent choices caused in any way by societal discrimination no matter how unreasonable or unpredictable such choices might be. Thus, while intervening choices do not necessarily break the causal chain of responsibility, they may suffice to do so under certain circumstances. The question is when.

In considering the relevance of intervening choice, legal doctrines that incorporate principles of corrective justice provide some helpful insights. The primary standard under proximate cause analysis for evaluating the relevance of intervening choice is foreseeability. ${ }^{175}$ An intervening choice may relieve the original wrongdoer of responsibility if the choice is not a reasonably foreseeable effect of the original wrongdoing. The virtue in the approach is its focus on the original wrongdoer's perspective. To the extent corrective justice bases responsibility on the causal agent's fault, the foreseeability inquiry appropriately focuses on what the wrongdoer should have anticipated as a consequence of his wrongful acts. The underlying principle is that one who could have foreseen that his wrongful conduct would cause the type of harm in question is fairly blamed for such harm. Conversely, one is not fairly held responsible for extraordinary consequences that could not reasonably have been anticipated.

Courts tend to extend proximate causation to a broader range of harmful consequences when the initiating wrongdoer's conduct was intentional or otherwise highly culpable. ${ }^{176}$ Indeed, there is substantial authority for the proposition that responsibility for intentional wrongdoing extends even to unforeseen consequences. ${ }^{177}$ To the extent the proximate cause analysis

175. See Hart \& Honoré, supra note 171, at 254-84; see also Abraham, supra note 161, at 118 ("The touchstone of proximate cause is foreseeability.").

176. As William Prosser observed, "[i]t has been said more than once that in cases of intentional wrong the law will be considerably more liberal to the plaintiff in finding liability for consequences." William L. Prosser, Transferred Intent, 45 TEX. L. REv. 650, 662 (1966). See also Restatement (Th1RD) OF ToRTs, $\S 33$ (b) (Tentative Draft No. 3, 2003) ("An actor who intentionally or recklessly causes physical harm is subject to liability for a broader range of harms than the harms for which that actor would be liable if acting negligently."); id. $\S 33$, Reporters' Note, cmt. e (explaining that the scope of liability is expanded for intentional or reckless torts as opposed to negligent acts);id. $\S 33$, Reporters' Note, cmt. e (noting that "[t]he idea that scope of liability is scaled to the degree of culpability for intentional tortfeasors is affirmed in Johnson v. Greer, 477 F.2d 101 (5th Cir. 1973) (applying federal law)")

177. For a list of some literature discussing the wider scope of causation in cases of intentional wrongdoing, see Richard W. Wright, The Efficiency Theory of Causation and Responsibility: Unscientific Formalism and False Semantics, 63 CHI.-KENT L. REv. 553, 575 (1987). See also Restatement (ThIRD) of TorTs $\$ 33$, Reporters' Note, cmt. e (Tentative Draft No. 3, 2003) (citing with parentheticals Caudle v. Betts, 512 So. 2d 389, 391 (La. 1987) (holding that where a defendant has committed a battery his liability extends to consequences that were unintended and could not be reasonably foreseen); Baker v. Shymkiv, 451 N.E.2d 811, 813 (Ohio 1983) (holding that damages caused by an intentional trespasser need not be foreseeable to be compensable); HART \& 
considers fairness to the original wrongdoer, the greater his wrongdoing, the less he should be heard to complain that the harm he caused was not intended or expected. While the animating principle is sound, the difficulty is in its application. What is reasonably foreseeable is highly dependent on the circumstances and is ultimately a matter of judgment. Nonetheless, the inquiry may be useful in assessing society's responsibility for selfdefeating or harmful choices by black people.

Applying the foreseeability approach to societal discrimination, the question is whether the condition of black people today, including the contribution of their choices, is a foreseeable result of slavery and discrimination on a society-wide basis, across numerous generations. Such conduct is highly culpable; the egregiousness of subjecting people, because of the color of their skin, to slavery, segregation, and discrimination cannot easily be exaggerated. Moreover, the racial discrimination at issue was intentional. Intentional acts of such blameworthy character suggest a long chain of proximate causation.

Nonetheless, one could argue that with the abolition of widespread legal discrimination in the $1960 \mathrm{~s}$, black people, once free to compete on equal terms, should have uplifted their condition and closed the gap. While some time would be required, the persistent and even worsening condition of many black communities could not reasonably be expected. Over thirty years after achieving legal equality, the persistent failure of blacks to better themselves can no longer, in fairness, be attributed to past societal discrimination. ${ }^{178}$ The availability of affirmative action and antipoverty programs during this time strengthen this argument. The choice by some black people, particularly young black males, with opportunities for education, meaningful work, and civic participation, to engage instead in menial labor, government dependence, drugs, and gangs is arguably not a foreseeable response to their circumstances even if those circumstances were caused in some degree by past discrimination.

It certainly is perplexing that some people eschew opportunities that, however challenging, would significantly improve the quality of their lives. Americans who value education, family, and honest work are understandably confused, frustrated, and even disgusted at the persistent cycles of failure among the black underclass. Yet the question is not whether the conduct of poor blacks would be foreseeable if carried out by those Americans who have not experienced the effects of societal discrimination. The question, rather, is whether such conduct reflects a predictable

HONORÉ, supra note 171, at 172 (explaining that courts will often decline to limit a defendant's liability to only foreseeable consequences when the defendant intended to do harm).

178. See HACKER, supra note 29, at 55-56 ("Most conservative Americans tend to disclaim responsibility for issues and tensions associated with race .... In their view, black Americans . . for at least a generation, have been given plenty of opportunities, so they have no one but themselves to blame for whatever difficulties they face."). 
response by those most acutely impacted by discrimination, those whose lives confront the full catastrophe of America's discriminatory history. If we sincerely endeavor to appreciate the nature and influence of past discrimination, we should recognize that the choices of so many black Americans have been and continue to be shaped by the intergenerational effects of class and caste. ${ }^{179}$

Class effects refer to conditions derived primarily from economic deprivation that tend to impair the opportunities of present and future generations. Black children reared in families without economic or educationaI resources are unlikely, as adults, to have gained the kind of skills, knowledge, and aspirations that many white children will have gained from the day-to-day experience of being raised by an educated or economically privileged family. This relative lack of experiential knowledge or understanding among black people in one generation will affect the beliefs and aspirations of the next. The result is not so much a lack of awareness of the norms by which middle-class society lives, but a lack of the internalization of those norms that comes from years of daily parental nurturing and guidance. It is true that a number of black people have made laudable and outstanding progress. But the reality for many black children, particularly in the inner city, is that the combination of concentrated poverty, drugs, crime, broken families, and lingering discrimination impairs their ability to make informed choices. Even after reaching adulthood, many of these ehildren will continue, predictably, to lack the aspirations, skills, and self-discipline they would have internalized in a family not damaged by past discrimination. The children born to these adults will likely, in turn, suffer similar consequences.

Caste effects are broader than class effects and include social statusbased discrimination that goes beyond the immediate disadvantages of poverty. Under the Hindu caste system of India, for example, a person's caste was not exclusively a function of one's economic condition, but was a social and religious trait inherited from one's family. ${ }^{180}$ Members of different castes werc expected to fulfill different roles, with severe sanctions imposed against those who sought to deviate from them. ${ }^{181}$ This system relegated lower castes to a life of menial labor often in service of higher castes, and subjected "outcaste" or "untouchable" people, deemed ritually unclean, to drastic forms of segregation. ${ }^{182}$ Marriage between castes,

179. Professor Ali Mazrui suggested the distinction between class and caste.

180. See Clark D. Cunningham \& N.R. Madhava Menon, Race, Class, Caste ...? Rethinking Affirmative Action, 97 MiCH. L. REv. 1296, 1305 (1999) (explaining that India's caste system was consistent with the "core meaning of caste as descent group").

181. See M. Vam Chandola, Affirmative Action in India and the United States: The Untouchable and Black Experience, 3 lND. INT'L \& CoMP. L. REv. 101, 103 (1992).

182. See Clark D. Cunningham, Affirmative Action: India's Example, Civ. RTs. J., Fall 1999, at 22,25 (explaining the hierarchy of India's caste system). 
particularly with the lowest castes, was socially proscribed. ${ }^{183}$ Perhaps most importantly, the inferior status of the lower castes was socially accepted both within and without those castes. ${ }^{184}$ The result is that ambitious laws enacted fifty years ago to abolish the caste system have had limited success in eliminating social caste distinctions, particularly with respect to those (formerly) known as "untouchables." One of the most difficult problems has been the extent to which members of traditionally lower castes continue to believe in the legitimacy of their inferior status. ${ }^{185}$

Racial discrimination in the United States was in substance a caste system. ${ }^{186}$ By virtue of an inherited trait, race, black people were socially and legally denied political, economic, and educational opportunities. They were segregated in housing, schools, and marriage, victimized by violence and intimidation, and subjected to an ideology of inferiority and exclusion. This ideology continues to affect both the way many black people think of themselves and the way white people react to them. The effects of racial caste shape people's preferences, values, and expectations, which in turn affect their choices. Moreover, blacks who do escape poverty do not necessarily avoid such social and psychological effects. They still encounter a world in which many Americans of all races doubt the character or competence of black people. The effects must be far greater on black children raised in families and communities marked by poverty, substance abuse, and crime, "those who learn from birth to expect and therefore to reach for little." 187

The analogy to the Indian caste system should not be overstated. India and the United States are different in many complex ways that I have not adequately described or explained. The point of the comparison is simply that a social system of inheritable subordination, deeply ingrained in a nation's culture and supported by law for numerous generations, will tenaciously persist over subsequent generations despite the abolition of legal distinctions.

Additionally, in considering the extent to which racial disparities today are a reasonably foreseeable consequence of past discrimination, it should be recognized that the discrimination was continuous. It was not an isolated, single event with speculative consequences stretching into the

183. See Cunningham \& Menon, supra note 180, at 1305 (noting extensive endogamy practiced by lower castes); Chandola, supra note 181, at 103 ("The Hindu caste system is a hierarchy of endogamous and permanent groups regulated by complex social codes and sanetions.").

184. See Rammanohar Lohia, The Caste System 85 (1964) ("[A] long tradion [sic] of ideological subjection has made [the lower castes] stagnate .... Centuries have instilled into them a meek acceptance of the existing [order].").

185. It is also noteworthy that the Indian people, through constitutional and statutory enactments, have accepted and continue to accept collective responsibility as a nation for the impoverishing impact of their caste system upon those historically relegated to the lowest social strata.

186. See sources cited supra note 141 .

187. RoBinson, supra note 6 , at 63 . 
future. Rather, society continuously discriminated against blacks year after year, generation after generation. Thus, the effects of such discrimination, and the need to rectify them, were continuously apparent. Society was an ongoing participant in the subordination of blacks and a continuing witness to the social and economic conditions that resulted. Thus, society cannot plausibly claim that America's racial divide today could not reasonably have been anticipated because the devastating consequences of centuries of wholesale discrimination were visible throughout the course of the discrimination.

The foregoing argument is only a sketch of the process by which the economic, social, and cultural effects of past discrimination perpetuate themselves through the children of each generation. Much more work is needed to understand more fully the legacy of American discrimination. The point of the preceding analysis is that black people's choices taken in response to past societal discrimination are not so extraordinary as to justify denying any societal responsibility for the results of those choices. When we endeavor to appreciate the intergencrational effects of societal discrimination on the subjective processes of its victims, the selfdestructive choices of those victims are, tragically, predictable. ${ }^{188}$ To conclude that their choices do not implicate the responsibility of society would seem to permit the cultural and psychological damage of societal discrimination to serve as its own excuse. When the predictable, insidious effects of a caste system come to pass, we should not relieve the caste creator of responsibility simply because the caste system has succeeded in enlisting its victims to aid in its perpetuation.

\section{The Significance of Time}

The passage of time itself provides another basis for limiting society's responsibility for effects of past discrimination. It has now been almost 140 years since the abolition of slavery and almost forty years since the Civil Rights Acts of the 1960s. At least two considerations support the claim that time may have diminished societal responsibility. First, regardless of the reason for delay, claims based on historic injustice arguably should dissipate with time. A kind of statute of limitations may apply to claims of

188. As Bernard Williams observes, equal respect for people who have endured oppression requires more than understanding their perspective; it requires understanding the extent to which oppression may have distorted their perspective:

For it is precisely a mark of extreme exploitation or degradation that those who suffer it do not see themselves differently from the way they are seen by the exploiters; either they do not see themselves as anything at all, or they acquiesce passively in the role for which they have been cast. Here we evidently need something more than the precept that one should respect and try to understand another man's consciousness of his own activities; it is also that one may not suppress or destroy that consciousness.

Bernard A. O. Williams, The Idea of Equality, in Justice AND Equalıty 116, 124 (Hugo A. Bedau ed., 1971). 
racial injustice. ${ }^{189}$ Second, even accepting that past discrimination explains much of black disadvantage, some commentators have questioned whether blacks have "slept on their rights." In delaying their claim for societal remediation, blacks may have forfeited their rights under a rule similar to the equitable doctrine of laches. ${ }^{190}$

This Article argues that American society has a moral, rather than legal, obligation to remedy past discrimination. Therefore, a statute of limitations does not apply. Nonetheless, the concerns that underlie statutes of limitations may suggest reasons why the passage of time since the legal abolition of slavery and segregation should extinguish society's moral obligation. Statutes of limitations serve several purposes. They encourage plaintiffs to bring litigation before evidence is lost or becomes unavailable. ${ }^{191}$ They also protect defendants against fraudulent claims brought after the facts become difficult to prove. ${ }^{192}$ Additionally, litigating cases where the court can determine facts efficiently conserves judicial resources. ${ }^{193}$ Finally, statutes of limitations provide a sense of finality or repose for defendants. ${ }^{194}$

On the other hand, other considerations counsel against imposing a limitation period. Such periods tend to be inapplicable or at least lengthier for especially important causes of action, such as prosecutions for the most wrongful crimes. ${ }^{195}$ Equitable grounds may also justify holding that a claim is not barred despite the passage of the statutory limitations period. Two such doctrines are equitable estoppel and equitable tolling. Equitable estoppel focuses on the defendant's fault in impairing the plaintiff's ability to

189. See BARKAN, supra note 155, at 288 (questioning whether a statute of limitations should apply to national injustices); ROBINSON, supra note 6, at 224 (noting the objection to a moral obligation on the part of the United States to make amends to blacks for past discrimination because "the wrongful action took place so long ago").

190. See Dan B. Dobbs, Handbook on the Law of Remedies 43 (1973). The issue has been discussed in the context of reparations on behalf of black Americans and other groups. See, e.g., Jeremy Levitt, Black African Reparations: Making a Claim for Enslavement and Systematic De Jure Segregation and Racial Discrimination Under American and International Law, 25 S.U. L. REv. 1, 22 (1997) (black Americans); Mari J. Matsuda, Looking to the Bottom: Critical Legal Studies and Reparations, 22 HaRv. C.R.-C.L. L. REv. 323, $381-82$ (1987) (Japanese Americans and Native Hawaiians); Donald Aquinas Lancaster, Jr., Comment, The Alchemy and Legacy of the United States of America's Sanction of Slavery and Segregation: A Property Law and Equitable Remedy Analysis of African American Reparations, 43 How. L.J. 171, 207 (2000) (black Americans).

191. See David E. Chawes, Time Is Not On Your Side: Establishing A Consistent Statute of Limitations For The Alien Tort Claims Act, 27 SeATtLE U. L. Rev. 191, 197 (2003).

192. Id.

193. Id.

194. Id.

195. See, e.g., 18 U.S.C. $\$ 3281$ (2001) (setting no statute of limitations for murder under federal law); $\S 799$ (West 2003) ("Prosecution for an offense punishable by death or by imprisonment in the state prison for life or for life without the possibility of parole, or for the embezzlement of public money, may be commenced at any time."); $c f$. CAL. PEN. CODE $\S 800$ ("Except as provided in Section 799 , prosecution for an offense punishable by imprisonment in the state prison for eight years or more shall be commenced within six years after commission of the offense."). 
bring a timely claim, "preclud[ing] a party from taking advantage of a predicament into which the party's own conduct has placed his adversary." 196 Equitable tolling focuses instead on the plaintiff, rclieving him of the statute of limitations when he has good cause for delay, such as where the plaintiff was unable to obtain or discover necessary facts, ${ }^{197}$ or where the plaintiff suffered from a legal disability. ${ }^{198}$ Finally, certain offenses, such as conspiracy, are viewed as "continuing" rather than as discrete incidents, and therefore do not trigger the running of the limitations period until they have terminated completely. ${ }^{199}$

Turning to society's obligation to remedy past discrimination, two points suggest time barring the obligation. First, the passage of time since the abolition of slavery and segregation has produced evidentiary difficulties with identifying the present victims of past discrimination and the extent of their injury. Second, America has an interest in repose, that is, relief from the unsettled and divisive controvcrsy surrounding affirmative action and reparations. At some point, for the sake of civil rest and the health of the collective American psyche, the admittedly unjust discrimination of the past should arguably be let go.

Notwithstanding these concerns, a number of considerations counsel against time barring society's obligation for past discrimination. First, and most importantly, there has in fact been no delay in seeking reparations and other remedial policies from American society in compensation for slavery and discrimination. Blacks (and whites) condemned slavery and demanded its abolition throughout its practice. Following slavery, throughout the nineteenth and twentieth centuries, blacks have sought to end discrimination, punish lynching, retain the right to vote, and have demanded remedial relief for the effects of slavery and discrimination. For example, during Reconstruction, blacks and their supporters sought congressional reparations in the form of land for the freed slaves. ${ }^{200}$ Similarly, at the turn of the twentieth century, blacks sought reparations for slavery from Congress through the Mason Bill, which would deliver reparations in the form of pensions to those individuals who lived through slavery:

[A]ny person who may have been held as a slave or involuntary servant under and by reason of any law of the United States, or of either of the States ... and who shall at the date of the passage of

\footnotetext{
196. Chawes, supra note 191 , at 200-01.

197. See id. at 201 .

198. See, e.g., Burrell v. Newsome, 883 F.2d 416, 418 (5th Cir. 1989).

199. See, e.g., United States v. Kissel, 218 U.S. 601 (1910); see generally Beverly L. Jacklin, When Is Conspiracy Continuing Offense for Purposes of Statute of Limitations Under I8 U.S.C.A. $\S$ 3282, 109 A.L.R. 616 (1992).

200. See Derrick Bell, Race, Racism \& American law 58-59, 59 n.l (4th ed. 2000) (citing Lerone Bennett, Before the Mayflower: A History of Black America 189 (5th rev. ed., Penguin Books 1984) (1961) (describing attempts in Congress to secure "Forty Acres and a Mule" for freed slaves made following Civil War)).
} 
this Act have reached the age of seventy years, shall be entitled to and receive the sum of five hundred dollars from the Treasury of the United States ... and to the sum of fifteen dollars per month during the residue of their natural lives. ${ }^{201}$

The bill would provide smaller sums to younger survivors of slavery. ${ }^{202}$ Demands for reparations continued through the civil rights movement of the twentieth century to the present. ${ }^{203}$

Moreover, such demands have been made in the face of relentless and often violent rejection. Indeed, any greater demands by blacks would likely have been met with even more brutal reprisals than were perpetrated against them throughout American history. Any delay in remedying past discrimination thus reflects society's delay in fulfilling its obligation, not the delay of blacks in demanding it. To recognize such delay as undermining America's obligation would be like time barring a defendant's liability for wrongful injury because the defendant delayed in responding to a plaintiff's timely complaint or in fulfilling a judgment of liability. Such delay might justify a default judgment, interest fees, and contempt against the defendant, not relief from liability.

Additionally, even if no one had argued for remedial policies until now, a limitations period would not in fairness begin to run until the late 1960s. Societal discrimination was continuous through slavery and segregation until the effective enforcement of the Civil Rights and Voting Rights Acts of 1964 and 1965, respectively, and the Supreme Court's invalidation of anti-miscegenation laws in 1967. The unjust conduct for which society is responsible thus did not end until recently. Furthermore, any delay in demanding remedial relief before the late 1960 s is excusable on equitable grounds. Society's discrimination against blacks, including disenfranchisement, educational and economic deprivation, and intimidation and violence, realistically precluded blacks from effectively seeking remedial legislation.

The disenfranchisement of blacks is worth emphasis. Following Reconstruction, blacks were effectively disenfranchised by the turn of the twentieth century, and remained so until the Voting Rights Act of I965

201. See S. 4718, 55th Cong. (1898). Supporters of the bill included an association of Louisianans who incorporated as the "Ex-Slave Mutual Relicf Bounty and Pension Association of Louisiana." See Act of Incorporation of the Ex-Slave Mutual Relief Bounty \& Pension Association of Louisiana, 22 June 1899, Notarial Acts of Louis Martinet, NONARC (cited in Rebecca Scott, Derechos y honra públicos: Louis Martinet, Plessy v. Ferguson y el acceso a la ley en Luisiana, 1888-1917 in DeBATE Y PERSPECTIVAS (forthcoming 2004) (Spain).

202. Id.

203. See, e.g., sources on reparations published each decade from the 1960 s to the year 2000 cited supra note 6; see also BELL, supra note 200, at 71-72, 668-69 (describing James Forman's presentation of his "Black Manifesto" in 1969 in which he demanded \$500 million in reparations). 
ameliorated the most significant obstacles to black political participation. ${ }^{204}$ The disenfranchisement of blacks made obtaining remedial legislation infeasible. As democratic theory would predict, the exclusion of political participation prevented blacks from seeking legislation in their interests, and eliminated any incentives among whites to form coalitions with blacks to lobby for mutually beneficial public policies. The rise of segregationist laws and practices that accompanied the disenfranchisement of blacks is thus not surprising.

Consider also the futility of demanding compensatory relief from a society that continued to protect state-sponsored and private discrimination. A society that continues to support discrimination is extremely unlikely to compensate willingly its ongoing victims for past discrimination. This assumption is borne out by Congress's rejection of the aforementioned efforts to obtain land and monetary reparations both during Reconstruction and at the turn of the twentieth century. Indeed, following the Civil War, the federal government not only rejected claims for reparations, it affirmatively reclaimed land that had been awarded to some former slaves. ${ }^{205}$ Even recent proposals that merely seek an apology for slavery and for a commission to study slavery and its effects have met cold receptions in Congress. ${ }^{206} \mathrm{~A}$ claim is not justly considered time barred when the defendant impaired the plaintiff's ability to pursue it sooner or when the institution that must approve the claim would not previously have recognized the claim's legitimacy.

Accordingly, the time that has elapsed since blacks can reasonably be expected to have sought compensatory relief has been just a few decades since the national abolition of state-sponsored discrimination. Assuming for the sake of argument that blacks have not sought reparations or affirmative action until now, the passage of a few decades, compared to the centuries of injustice that preceded them, is hardly too long. It took almost fifty years between the internment of Japanese Americans and the enactment of congressional reparations, and that was for an injustice of far more limited scope and duration. ${ }^{207}$ Recall also that the seriousness of the claim counsels

204. See Shaw v. Reno, 509 U.S. 630, 640 (1993) (describing the history of black disenfranchisement in the South and the success of the Voting Rights Act of 1965 in significantly reducing the gap between white and black voting participation).

205. See BENNETT, supra note 200, at 223-24 (describing how President Johnson pardoned former confederates and returned land to them in South Carolina that had been awarded to former slaves).

206. See 143 Cong. Rec. H3890-06 (daily ed. June 18, 1997) (statement of Representative Tony Hall in dcfense of the proposed congressional resolution to apologize for slavery); BELL, supra note 200, at 69 n.4 (describing the bill sponsored by Representativc John Conyers to establish a commission to study slavery, postslavery discrimination, and their effects on living blacks, and noting that the bill has repeatedly failed to come out of committee).

207. See Civil Liberties Act of 1988, supra note 130 (providing for apology and reparations to Japanese Americans and Aleut Americans for the U.S. relocation and internment policy during World War II). 
against application of a statute of limitations. Slavery and discrimination against blacks was egregiously unjust, which conservatives now emphasize in claiming that all racial discrimination is per se unconstitutional.

The foregoing considerations suggest that despite concerns over loss of evidence and repose, the delay in seeking relief required to trigger the running of a limitations period has not occurred. To the extent it has, however, the limitations period should be estopped or tolled on equitable grounds. The concern over repose, moreover, is itself inadequate to time bar society's responsibility. First, although social tension over past discrimination is undesirable, refraining from remedying the effects of discrimination is not the most effective or appropriate response. Policies designed to remedy past discrimination are not the sole or even primary source of America's racial problems. The cultural, socioeconomic, and political divide between blacks and whites long predates the contemporary affirmative action debate. Indeed, the extent to which blacks and whites live in two nations reflects the long-term effects of societal discrimination, conditions which foster racial friction and reinforce stereotypes. Remedying the conditions that divide Americans along racial lines should be as likely to reduce social tensions as to exacerbate them. Second, any social friction surrounding efforts to remedy past discrimination cannot justify denying such relief if the friction stems from society's refusal to recognize its remedial responsibility. Legitimate claims for equal rights have often stirred resentment among those who would persist in discrimination, ${ }^{208}$ but that has not served as a legitimate ground to protect the status quo. If it were, then the abolitionist and civil rights movements should never have been attempted. The difficulty of identifying the effects of past discrimination is a legitimate concern. As the next Part argues, however, the difficulty is insufficient to excuse morally society's obligation to engage in remedial efforts.

The claim that black people have "slept on their rights" is unpersuasive for reasons similar to those discussed in relation to application of a limitations period. The defense of laches requires unreasonable delay committed by the plaintiff in seeking relief. ${ }^{209}$ First, as explained above, blacks have not delayed in seeking remedial relief from the oppression of slavery and discrimination. Second, as also discussed, any delay on the part of blacks was not unreasonable, given the nature of society's ongoing discrimination against them.

In short, America practiced slavery for two and a half centuries and enforced a regime of legal and social caste for at least another hundred

208. See Randall Kennedy, Persuasion and Distrust, A Comment on the Affirmative Action Debate, 99 HARV. L. REV. 1327, 1330 (1986) (describing bitter resistance to the civil rights movement).

209. See Restatement (SECOND) OF Torts $\S 939 \mathrm{cmt}$. a (1979). 
years. Throughout all of those years, voices of protest were raised and ignored. In the few decades since the civil rights movement, society's efforts to address the effects of a long history of discrimination have been minimal and halting. Black people have not slept on their rights; American society has persisted in denying them.

III

Mediating the Moral Conflict: How Can Society FULFILL ITS RESPONSIBILITY?

This Article has primarily considered the existence of societal responsibility for the effects of past discrimination. The plausibility of a societal obligation to remedy such effects undermines the proposition that if racial discrimination is wrong, then society is obligated, without exception, to refrain from enacting remedial race-conscious policies. The competing moral obligation of society toward the millions of individual black Americans who suffer from the effects of past discrimination suggests a difficult dilemma. To resolve the dilemma, society must balance these competing claims, taking into account their comparative moral weight, and must consider the extent to which honoring one obligation dishonors the other.

Although a detailed remedial proposal is beyond the scope of this Article, this Part raises some of the salient issues that may arise in the design of remedies and suggests some potential lines of analysis for resolving them. Part III.A considers the difficulty of identifying the effects of past discrimination with the particularity necessary to address them. Any uncertainty in identifying the victims of past discrimination and the scope of their injury complicates the process of tailoring remedies to address actual harm and heightens the risk that the burdens of any such policies will outweigh the benefits. Part III.B considers what corrective approaches would be most effective in remedying the effects of societal discrimination, specifically, how to reverse the intergenerational effects of past discrimination and how long such a process might take. These questions are monumental, and this Article does not provide definitive answers. The goal, rather, is to chart a course of inquiry, the completion of which will require the expertise of social scientists and the political will of Americans and their leaders.

\section{A. The Difficulties of Identifying the Effects of Past Discrimination}

Identifying the effects of past societal discrimination involves two serious difficulties. First, assuming that effects of past discrimination persist, their magnitude is unclear. The prima facie case outlined previously relies substantially on the existence of racial disparities between blacks and whites to infer that past discrimination continues to have an impact. It assumes that, absent discrimination, people of different races would occupy 
social and economic strata in at least rough proportion to their percentage in the population. Such an assumption may be unrealistic. Some variation among racial groups may exist without a racially discriminatory cause. There are, moreover, racial groups that have experienced a substantial degree of discrimination without falling or remaining below whites in economic success. As it is highly speculative what the status of black people across a variety of contexts would be today absent past discrimination, it is highly speculative what the magnitude of society's responsibility may be.

Second, the individual victims of past societal discrimination are not readily identifiable. Since some black people would be relatively disadvantaged even without past discrimination, just as some white people are, some disadvantaged blacks may not be any worse off than they would be absent past discrimination and are therefore not harmed by such discrimination. In addition, some privileged blacks may have overcome past discrimination while others, though relatively well off presently, would be wealthier had past discrimination not been practiced. If, as a matter of corrective justice, a harm-causing agent's responsibility extends only to those it has harmed, it is arguably impossible to satisfy societal responsibility without knowing the identity of the victims of discrimination.

Concededly, the degree to which present conditions are attributable to past discrimination is unclear. Some imprecision, though, is inevitable in any efforts to achieve corrective justice. For example, in cases arising from mass torts, the processes for determining the existence and extent of liability, including admissibility and reliability of evidence, burdens of proof, and measures and allocations of damages, involve estimations with risks of error that are inevitable in any viable system of corrective justice. ${ }^{210}$ Likewise, in enacting broad-scale policies, legislatures must often rely on uncertain factual findings and consequences. We need to decide collectively how much imprecision to tolerate in remedying past discrimination, recognizing that millions of injustices will likely go unremedied if nothing is done.

It is noteworthy that conservatives are willing to tolerate a significant degree of imprecision when racial discrimination is used for law enforcement. The practice of "racial profiling," which conservatives tend to support more than liberals, ${ }^{211}$ involves racial discrimination in the selection of

210. See Glen O. Robinson \& Kenneth S. Abraham, Collective Justice in Tort Law, $78 \mathrm{~V}_{\mathrm{A} .} \mathrm{L}$. REv. 1481 (1992) (arguing that no eredible system of corrective justice requires complete certainty and precision in adjudicating and allocating eompensation in tort claims and, indeed, corrective justice may require collective adjudieation despite its imperfeetions); see also Brest \& Oshige, supra note 14, at 865 (noting that the model of an identifiable victim has been relaxed in class action cases).

211. See Samuel R. Gross \& Debra Livingston, Racial Profiling Under Attack, 102 Colum. L. REv. 1413, 1422 (2002) (noting that eonservatives were the only vocal supporters of racial profiling before September 11, 2001). 
suspects. Although the vast majority of suspects are innocent, ${ }^{212}$ conservatives justify the practice as necessary in the war on drugs and, more recently, in the war on terrorism. ${ }^{213}$ One conservative commentator, for example, in justifying the profiling of airplane passengers, acknowledged that " $\mathrm{t}] \mathrm{he}$ odds that any Middle Eastern passenger is a terrorist are, of course, tiny." 214 Profiling supporters view the burden to innocent minorities mistakenly suspected of criminality as regrettable, but necessary, a kind of "racial tax," as Professor Randall Kennedy terms it, ${ }^{215}$ paid in the interest of crime control. Similarly, conservatives should view the imprecision of remedial programs as a regrettable but necessary cost of remedying historic discrimination. The more conservatives emphasize the injustice of racial discrimination, the more compelling they should view America's interest in remedying its harmful consequences. As such, they should tolerate substantial imprecision in pursuit of such a pressing objective.

The problem that victims of past societal discrimination are largely unidentifiable is real and likely to worsen with time. The largely anonymous nature of societal discrimination and its longevity over generations make identification of its victims difficult. However, some points in favor of pursuing remedial policies exist. First, it seems unfair to relieve society of responsibility because society has neglected to remedy its wrongs for so long that its victims are difficult to identify precisely or to make whole. Similar concerns in the adjudication process underlie the doctrine of spoliation, which denies to a wrongdoer the benefit of lost evidence attributable to the wrongdoer's fault. ${ }^{216}$

Second, we know the victims likely exist and are concentrated among blacks, and that they probably number in the millions. This should give us pause before absolving society of fulfilling its responsibility for wrongfully caused harm simply because rectifying it may be costly or may benefit some nonvictims. Any risk of benefiting nonvictims should be weighed against the harm attributable to the failure to compensate actual victims.

212. See id. at 1423 (explaining that "[e]ven if race or ethnicity is a strong predictor of criminal behavior, an individual member of the relevant groups is very unlikely to be a criminal," and noting spccifically that "only a tiny proportion of Middle Eastern men are affiliated with al Qaeda").

213. See id. at 1415 (explaining that "[racial profiling] has received particular attention in the context of highway drug interdiction, and more recently, of course, in investigations of terrorism").

214. Stuart Taylor, Jr., The Skies Won't Be Safe Until We Use Commonsense Profiling, NAT'L J., Mar. 16, 2002, at 11.

215. See Randall Kennedy, Race, Crime, and the Law 159 (1997).

216. The legal maxim omnia praesumuntur contra spoliatorem has for centuries expressed the rule that an unfavorable inference may be drawn against a party responsible for the destruction or loss of evidence. See Jamie S. Gorelick et al., Destruction of Evidence $\$ 2.1$, at 32 (1989). Courts have traditionally required that the spoliation of evidence be intentional for this inference to be drawn, but more recent cases have allowed negligent spoliation to "create a rebuttable presumption that establishes the missing elements of the plaintiff's case that could only have been proved by the availability of the missing evidence." Welsh v. United States, 844 F.2d 1239, 1248 (6th Cir. 1988). 
Balancing the costs of not remedying past societal discrimination with the costs of remedying through "reverse" discrimination should consider the wrongfulness and magnitude of the respective discriminations. Societal discrimination against blacks was arguably worse than remedial discrimination against whites both in purpose and effects. Societal discrimination against blacks was intended to subjugate them based on the belief that they were inferior people unfit for and undeserving of equal rights. Discrimination against whites to remedy societal discrimination, in contrast, is intended to undo past discriminatory wrongs against blacks. The victims of affirmative action are not presumed to be unfit or inferior but are treated as regrettable means to a legitimate remedial end. Whatever wrongfulness inheres in such treatment, it is not motivated by a comparably repugnant ideology.

The effects of societal discrimination are also more injurious than those of affirmative action upon their respective victims. Societal discrimination against blacks was extremely broad, denying blacks access to whole fields of endeavor. Blacks experienced discrimination on a frequent, comprehensive basis from an early age, which fundamentally impaired their life opportunities and, in turn, those of their children. Victims of affirmative action, in contrast, generally experience isolated burdens unlikely to impair significantly the economic quality of their lives or those of their children. A white applicant denied admission by a school of higher education, for example, will generally have opportunities for a comparable education elsewhere, although not at the institution of first choice. The vast majority of such applicants will achieve careers as lucrative as they would have absent the discrimination, and it is unlikely that their children will be raised with familial resources substantially inferior to those they would have enjoyed absent affirmative action. ${ }^{217}$

Although some opponents of affirmative action might dispute any moral difference between societal discrimination and discrimination for benign purposes, ${ }^{218}$ the Supreme Court, as a whole, does not. In explaining

217. Professor Strauss has also argued that societal discrimination is worse than isolated acts of discrimination or discrimination limited to particular contexts. See David A. Strauss, Affirmative Action and the Public Interest, 1995 SUP. CT. REV. 1, 15 ("[I]f the premise is that racial classifications are generally harmful, one would want them employed only to remedy the greatest evils, and offhand societal discrimination seems like a greater evil than discrimination in a specific area.").

218. Justice Clarence Thomas purports to hold this view, arguing that affirmative action is the "moral equivalent" of discrimination against blacks. Adarand Constructors, Inc. v. Pena, 515 U.S. 200, 240 (1995) (Thomas, J., concurring in part and concurring in the judgment) (reasoning that raeial classifications to benefit blacks warrant strict scrutiny because there is a "moral [and] constitutional equivalence" between such classifications and discrimination against blacks). It is questionable whether he believes this view completely. Despite his advocacy of colorblind governmental decision making, Thomas strongly defended the legitimacy of historically black eolleges, arguing that their historical role in sustaining black people and culture during segregation justifies their maintenance. See United States v. Fordice, 505 U.S. 717, 748 (1992) (Thomas, J., concurring). I assume Justice Thomas would not defend the maintenance of historieally white colleges, at least given the absence of a similar historical 
the application of strict scrutiny to apparently benign uses of race, the Court said it was ensuring against the risk that the discrimination was actually motivated by illegitimate prejudice or stereotype. ${ }^{219}$ Racial discrimination motivated by illegitimate purposes is unconstitutional whereas discrimination for compelling purposes is not. ${ }^{220}$ Although the Court has invalidated preferential discrimination designed to remedy societal discrimination, it has not viewed such discrimination as equivalent to discrimination based on prejudice but rather as too "amorphous" to rule out the risk that a policy ostensibly designed to remedy societal discrimination was in fact motivated by illegitimate stereotype or prejudice. ${ }^{221}$ With respect to the character of past societal discrimination against blacks, in contrast, there is not merely a risk of racial prejudice, it is a certainty. Accordingly, if past societal discrimination against blacks is a greater moral wrong than current discrimination against whites to remedy its effects, then the failure to remedy societal discrimination is a greater moral wrong than the discrimination involved in remedying societal discrimination.

Underlying the foregoing discussion is a point worth explicit emphasis-inaction is not morally neutral. The failure to fulfill a duty to remedy injustice is as morally problematic as originating the injustice. Corrective justice theory requires the rectification of harm by the wrongdoer that caused it. Correcting the injustice is a moral imperative, the failure of which is a moral wrong. ${ }^{222}$ The implications for societal discrimination are that the failure to remedy its effects or make its victims whole is as morally problematic as overremedying the same, that is, overcompensating its victims or compensating nonvictims. If refraining from affirmative action or other remedial measures would leave greater injustice unremedied, then societal inaction is a greater moral wrong than affirmative action.

\section{B. Designing Effective Remedies}

Assuming that American society is responsible for remedying the intergenerational effects of her discriminatory history, the question remaining is how to fulfill such responsibility effectively. The significance of this challenge should not be underestimated, nor is it within the scope of this

role. If my assumption is correct, then Justice Thomas does in fact believe that the purpose behind a race-conscious policy is relevant to its moral and legal legitimacy.

219. See City of Richmond v. J.A. Croson Co., 488 U.S. 469, 493 (1989) (explaining the purpose of strict scrutiny is to "smoke out" illegitimate prejudice, stereotypes, or simple racial politics).

220. See id. (explaining that in order to ensure that racial preferences are not in fact motivated by illegitimate prejudice or stereotypes, only those preferences that are narrowly tailored to achieve a compelling goal are constitutional).

221. See Kim Forde-Mazrui, The Constitutional Implications of Race-Neutral Affirmative Action, 88 GEO. L.J. 2331, 2369-7 I (2000) (explaining reasons behind the Court's holding that remedying societal discrimination is insufficiently compelling to justify racial preferences under strict scrutiny).

222. See Thomson, supra note 102 , at 149. 
Article to examine specific proposals. That important task will require the collective effort of political leaders, social scientists, public interest organizations, and other interested persons and groups.

Nonetheless, corrective racial justice has some implications for the design of remedial policies. As corrective justice is concerned with correcting the harmful effects of wrongdoing, the ideal remedy would place the victims of wrongdoing in the same position they would have been in had the wrongdoing never occurred. The link between slavery and the presence of blacks in America complicates this inquiry. Had slavery not been practiced, the number of black Americans would likely be significantly lower. Even if, through immigration, a large number of blacks came to live in America, those persons would be different from many of the specific black people alive today, who came into being because their ancestors met as a result of slavery. What remedy would compensate one who would not exist absent the conduct to be remedied? Putting black Americans in the exact position they would be in absent past discrimination is thus impossible.

A remedy is, however, still appropriate. The harm to blacks alive today resulting from past discrimination is not limited to the enslavement of their ancestors. Society's wrongdoing is as recent as the present and immediately preceding generations. Had society accorded true legal equality and provided adequate opportunities to the freed slaves or to generations since, blacks alive today and born tomorrow would be raised under better conditions. Each black child, born into a family and community with educational, economic, and cultural resources inferior to what they would be, had the child's parents', grandparents', and great-grandparents' generations been accorded equal rights and adequate remedial support, suffers a new wrong that society can remedy by providing opportunities to the present generation.

As to the precise nature of remedial policies, corrective justice suggests policies tailored to the nature of the harm suffered by the victims of past discrimination. As discussed above, the harm includes a lack of educational achievement, economic resources, and cultural and psychological well-being. This suggests that remedial programs should be designed to provide educational and economic opportunities, and to strengthen familial and community institutions that foster self-respect and personal responsibility. The harm warrants sensibly designcd antipoverty, school improvement, job training, health care, and crime prevention efforts supported by sufficient resources. Holding individual black people responsible for criminal conduct is also required to reinforcc personal responsibility, although the socioeconomic conditions that foster such behavior must also be addressed.

Society can also take steps to minimize the problem of victim identification discussed in Part II.A. By investigating family histories, one could 
identify many of the victims of past discrimination with some confidence. For example, poor black Americans whose families have lived in the United States for several generations are likely to have experienced intergenerational effects of societal discrimination. Additionally, collateral harm could be minimized by designing remedial programs to serve legitimate purposes in addition to that of remedying racial discrimination. In that way, to the extent undeserving beneficiaries, that is, nonvictims of discrimination, were benefited by remedial policies, their benefit would be justified for alternative reasons. For example, programs to improve public schools could be justified in part to fulfill society's responsibility to remedy past discrimination and in part to serve legitimate interests in educating poor children, or all children. The presence of an additional, legitimate goal should reduce concerns over unidentified victims. Requiring society as a whole, rather than a private litigant, to take remedial action is particularly appropriate where the most effective remedy is necessarily broad. Wc as a society may collectively decide to fulfill a remedial obligation in ways that also involve expenditures for other purposes, whereas it may be unfair to impose adjudicatively on a private defendant costs for purposes other than fulfilling the scope of his liability. ${ }^{223}$ This is not to condone looseness in designing remedial programs. We should target the effects of societal discrimination as precisely as possible. The point is that to the extent uncertainties in identifying the effects of past discrimination make some imprecision inevitable, we can ameliorate the costs of imprecision by designing remedial programs to serve additional legitimate interests.

We should not, however, underestimate the magnitude of the effort needed. The successful remediation of past discrimination would require that black children on average grow up from birth with advantages roughly equivalent to those of white children. What would it take for families who currently have little educational training or economic resources and who more broadly lack the psychological and cultural capital necessary to succeed in this economy to reach a level comparable to average middle class (mostly white) families? A massive infusion of resources into poor black communities would certainly improve the opportunities for the present generation of black children living there. But it is difficult to see how one generation of effort would suffice. The benefits of enhanced economic and educational opportunities for children whose families otherwise lack the personal experience to take full advantage of them seem unlikely to equal the benefits to children born into families with not only comparable

223. In fact, however, sometimes we do impose costs on private litigants in the form of exemplary or punitive damages that exceed the measure of damages caused by their wrongdoing. This illustrates that under certain circumstances the risk, indeed the certainty, of overcompensating victims may be warranted because the egregiousness of the wrongdoer's conduct justifies exacting additional payment for purposes other than compensation. 
resources but also the internalized norms and values that enable parents, on a daily basis, to nurture their children's characters accordingly. It will take several generations at least before the collective expenditure of resources from without can enable impoverished black families to transform themselves from within to the point that their children escape the damage of discrimination inflicted on prior generations. Moreover, the resources we devote to such efforts must be sufficient to overcome the tendency of poverty and of a societal culture embodying messages of racial inferiority to retard self-development and community building. We must be patient, mindful of how long our American forefathers maintained the subordination of black people. Centuries of slavery and legal oppression will takc time and generations to undo. Exactly how long will depend on the sincerity of our efforts.

We should also be wary of diversity-based programs as a substitute for programs designed to remedy past discrimination. Because the Supremc Court endorses diversity, but not remedying societal discrimination, as a justification for racial preferences, some proponents of remedying past discrimination may be satisfied with the pursuit of diversity as an indirect means for pursuing the remedial goal. ${ }^{224}$ Such satisfaction, however, may be misplaced. The pursuit of diversity is not only less effective at remedying past discrimination than pursuing the latter goal directly, it may ultimately doom the remedying of past discrimination by creating the illusion that past discrimination has been remedied when it has not. To the extent diversity-based programs benefit nonblack ethnic groups, such programs may, reassuringly, reduce the economic gap between whites and minorities generally, but do so without actually benefiting the victims of past discrimination who are likely to be black. Even if the status of blacks were monitored specifically, diversity-based programs may create a false impression that past discrimination is being addressed by benefiting blacks who are not victims of past societal discrimination, such as recent black immigrants. Such programs may thus close the black-white gap with the

224. See Timothy L. Hall, Educational Diversity: Viewpoints and Proxies, 59 Oнı ST. L.J. 551, 594-95 (1998) (noting dissatisfaction among legal scholars with the Supreme Court's rejection of remedying societal discrimination as a justification for affirmative action, and suggesting that diversity rationale provides a cloak to pursue that remedial goal); Gabriel J. Chin, Bakke to the Wall: The Crisis of Bakkean Diversity, 4 WM. \& MARY BILL OF RTS. J. 881, 930 (1996) ("For those who support affirmative action but cannot convince themselves that it is primarily justified by anything other than remedying past discrimination or distributive justice, the diversity fig leaf exists as a pretext."). As one commentator stated,

I have yet to find a professional academic who believes the primary motivation for preferential admissions has been to promote diversity in the student body for the better education of all the students while they are in professional school. Diversity is undoubtedly one reason for such programs, but the justification of countering the effects of societal discrimination ... comes closer to stating their central purpose ....

Kent Grcenawalt, The Unresolved Problems of Reverse Discrimination, 67 CALIF. L. REv. 87, 122 (1979). 
wrong blacks, that is, with blacks who were not harmed by past societal discrimination. The apparent elimination of racial disparities could thus deceive us into believing we have repaired the past when we have only obscured it. Care in tailoring remedial programs to reach the victims of past discrimination thus serves not only fairness, but effectiveness.

Finally, several advocates have called for a societal remedy in the form of cash payments to the descendants of slaves and victims of legalized discrimination. ${ }^{225}$ If the objective of remedying societal discrimination should be to eliminate the conditions of disadvantage, broadly defined, that disproportionately impact black Americans and that tend to perpetuate themselves intergenerationally, then monetary reparations, at least in a single payment, are unlikely to be a sufficient solution. First, aside from the difficulty of determining the amount and recipients of payments, the amount of funds necessary to undo the nationwide effects of past discrimination would likely be too great for our country to afford at one time. Second, and perhaps more importantly, monetary compensation seems unlikely to redress the nature of societal discrimination's damage. The cultural, spiritual, and aspirational damage caused by societal discrimination is unlikely to be cured by a lump sum payment to particular individuals. A payment of money is unlikely to substitute adequately for the family and community nurturing that black children need to thrive as they would had our nation accorded equality to prior generations. Furthermore, the impairing impact of societal discrimination on the norms and aspirations of many poor black people suggests that a cash payment by itself may be squandered in ways that fail to transform how their children are raised. This is not to deny that some reparations may be appropriate, but to disclaim such a remedy as sufficient by itself. What is needed for black children and families are long-term opportunities for self-development, opportunities to play, to learn, and to work in a cultural environment that nurtures selfesteem. Society's responsibility is not so much to give black people fish, but to teach them how to fish and to provide meaningful access to America's main stream.

\section{Conclusion}

The history of America's relationship with its black members has and continues to be one of the most fundamental challenges to a nation founded on principles of equality and justice. In the I960s, American society largely accepted responsibility for that history, concluding that legalized discrimination could no longer be tolerated and that its injurious effects would require affirmative efforts to correct. Societal support for remedial efforts has waned since that time in the belief or hope that America's

225. See sources cited supra note 6 (advocating reparations to blacks). 
discriminatory history is just that - history. Many believe that the effects of societal discrimination have largely dissipated or are too indeterminate, that present society is not fairly chargeable with the cost of remedying discrimination in which its members did not personally participate, and that the persistence of disadvantage among black people must increasingly be attributed to their own choices. Although Americans once viewed them as a societal obligation, we increasingly view efforts to remedy the conditions experienced by blacks as unjustified and, indeed, as unjust.

The claim that remedying past societal discrimination is morally prohibited, and not just unnecessary or undesirable, is not limited to the political realm. The Supreme Court has turned to morality to inform its interpretation of the constitutionality of affirmative action to remedy past discrimination. The Court reasons that affirmative action designed to remedy societal discrimination, at least through racial preferences, is unconstitutional because it is immoral.

This Article has sought to take seriously the moral concerns purportedly animating the conservative judicial and political movement against affirmative action, using legal tools of analysis to illuminate the primary issues involved. It has argued that principles relied on by opponents of affirmative action - that racial discrimination is immoral and that its victims should be made whole-support a moral obligation on the part of American society to remedy the effects of past societal discrimination against black Americans. The plausibility of the case for a societal obligation, at the very least, raises doubts about the opposing position that politically enacted remedial efforts are morally prohibited. Such uncertainty about the moral status of remedial affirmative action implies uncertainty about its constitutional status, uncertainty that arguably should be left to the political process to resolve. American society should, therefore, be constitutionally permitted, if not required, to take responsibility for the legacy of past discrimination.

The limits of this claim warrant reemphasis. This Article has not attempted to prove that society is legally obligated to remedy past societal discrimination, and acknowledges the disputability of a moral obligation as well. Nor has it claimed that society is exclusively responsible for the status of blacks. There may be, moreover, instrumental concerns not considered here with some kinds of remedial policies. The claim of this Article is that the principles that raise moral concerns over affirmative action, as well as concepts developed in the law for resolving questions of causation and responsibility, suggest that American society bears some responsibility for the inferior position of black Americans that has resulted in part from America's history of racial discrimination. If this argument has overlooked or underappreciated important points that negate society's responsibility, I 
invite others to respond. If not, and opponents of such responsibility persist in their opposition, then I ask: What, really, are their concerns?

In conclusion, we return to a question raised in the opening of this Article: Will the color line be the problem of the twenty-first century? Perhaps. However, coming to terms with our racial history need not evoke fear or dread if the nature of society's responsibility and its implications are properly understood. To the extent current society is obligated to redress the effects of past discrimination, such responsibility stems from justice, the fulfillment of which should give us pride, not shame. Such a commitment, morcover, would neither negate the personal responsibility of those black Americans who experience the detrimental effects of past discrimination, nor imply personal blame on the part of current members of society who must bear the cost of society's obligation. American society ought to address those conditions that perpetuate immiseration among a disproportionate number of our fellow Americans of the black race. Such efforts may include, indeed must include, holding accountable those entitled to our support. A principal harm of past discrimination is hopelessness and self-destructiveness. Holding people responsible for their actions is an important factor in remedying these cultural and psychological conditions. But it is not enough to punish individual wrongdoers and provide only superficial opportunities that the damage of discrimination realistically precludes many blaek people from even attempting to grasp. We as a society need to invest effectivcly in building the self-esteem, aspirations, and achievements of black children, families, and communities. And we must persist in the face of failure until we succeed. We know what to do; we need the political will, and patience, to do it. There is virtue in the effort. In so doing, the problem - the challenge-of the twenty-first century can be the pride of the next. 
